\title{
Exchange-rate Exposure and Brexit: The case of FTSE, DAX and IBEX
}

\author{
Athanasios Andrikopoulos*, Xeni Dassiou ${ }^{\dagger}$, Min Zheng ${ }^{\star}$
}

\begin{abstract}
This paper studies the impact of the United Kingdom's June 2016 referendum to withdraw from European Union membership ("Brexit”) on foreign exchange $(F X)$ exposures. We collect weekly data from 26 FTSE100, 10 IBEX35, and 17 DAX30 nonfinancial multinational companies before and after the referendum. The referendum is shown to have had a positive and significant impact on the returns of the FTSE100 firms. Following the Brexit vote, firmlevel $F X$ exposures increased significantly (in absolute terms) for the 26 FTSE100 firms included in this study; however, this was not the case with the IBEX and DAX firms. On the other hand, the Brexit vote led to a reduction in exchange rate exposure at the market level. $F X$ exposures in all three markets are reduced in absolute terms. Asymmetric specification models detect more German firms with significant $F X$ exposures. After accounting for cross-sectional dependence in the residuals of firms within the same country, the majority of our findings are robust.
\end{abstract}

Keywords: Foreign exchange $(F X)$ exposure; Asymmetric $F X$ exposure; Brexit. JEL Classification Numbers: G15, F31, D22*

Athanasios Andrikopoulos, Hull University Business School, Hull HU67RX, UK, A.Andrikopoulos@hull.ac.uk; ${ }^{\dagger}$ Xeni Dassiou, City University of London, London EC1V0HB, UK, Tel. +44 (0)20 7040 0206, x.dassiou@city.ac.uk; ${ }^{\star}$ Corresponding Author: Min Zheng, China Institute for Actuarial Science, Central University of Finance and Economics, Beijing 100081, China, mzheng@ cufe.edu.cn. We wish to thank Mr. Iain Fleming for collecting the data.

" Financial support from the National Natural Science Foundation of China (No. 71571197) and the 111 Project (No. B17050) is gratefully acknowledged. 


\section{Introduction}

On June 23, 2016, the United Kingdom (UK) voted to exit the European Union (EU), effective in 2019. This referendum caused turmoil in the foreign exchange and global stock markets, with the British pound (GBP) losing close to $15 \%$ of its value relative to the US dollar (USD) in the weeks following the referendum. Undoubtedly, the referendum was expected to initiate and deliver a complex combination of costs and benefits and is likely to cause significant operating risks for many nonfinancial companies (Dhingra, et al., 2016).

Research on the impact of the Brexit referendum is becoming more pertinent as the UK comes closer to leaving the EU, as a way to gain valuable insights into the impact of the actual Brexit event on foreign exchange $(F X)$ exposures. We study the impact of the Brexit referendum at the individual firm and overall market levels of $F X$ exposures by using a sample of British, Spanish, and German nonfinancial companies. Griffin and Stulz (2001) argue that firms might have high exposure coefficients but that such exposures may cancel each other out within industries because some are positive and others negative. Hence, $F X$ rate shocks may be significant at the firm level but are diversified at the industry level.

We, therefore, focus on the firm level and collect a sample of publicly traded multinational companies (MNCs) from the UK, Spain, and Germany. Comparing the UK's nonfinancial sector to the nonfinancial sectors in Spain and Germany allows us to evaluate the impact of the

referendum against a country with a similar stock market size (Spain) and a world-leading country (Germany) that both operate within the EU. 
The 26 UK nonfinancial companies selected in this study comprise $31 \%$ of the market capitalization of the FTSE100, including firms such as AstraZeneca (AZN), Diageo (DEO), and Glaxo Smith Kline (GSK) that lead the index. ${ }^{1}$ The 10 nonfinancial firms selected from Spain's IBEX35 account for $21 \%$ of the index by market capitalization, with Industria de Diseno Textil (ITX) and Ferrovial (FER) alone representing roughly 13\% of the index market capitalization. Germany's DAX30 index is dominated by manufacturing firms. The 17 manufacturing firms selected comprise $58 \%$ of the market capitalization of the DAX30.

We select Spain and Germany as the number of firms in each of these two markets is comparable, allowing a comparable assessment of the impact of the Brexit vote. In addition, we select Germany and Spain since they have strong trade links with the UK. Germany is the UK's largest EU trading partner, while Spain is the fifth largest (Department for International Trade, February 2019). Begg (2017) argues that supply chains are strongly interconnected. This argument is supported by the Financial Times (2018), which argues that the German economy should be concerned about a 'no deal Brexit' (a situation in which the UK exits the EU by the required deadline with no formal agreement in place) as tariffs may have a significantly negative impact on exports. Another reason for selecting Spain is the size of its financial market; the number of listed firms exceeded 3,000 in Spain (Table 1, Panel A), while the UK had more than 2,000 firms and Germany had approximately 500 firms during the period under study. With more than 3,000 firms, Spain is one of the top 10 largest stock markets in the world by number of firms; the UK, with greater than 2,000 listed firms, immediately follows Spain in size.

Brexit poses uncertainty for the value of the GBP and how the UK trades and generally interacts with the EU. Rhodes (2018) argues that a weaker pound implies British goods will be cheaper abroad, boosting sales and profits but may negatively affect import-based supply

\footnotetext{
${ }^{1}$ Shire Plc was part of FTSE100 but was acquired by Takeda Pharmaceutical Company in January 2019.
} 
chains as a weaker pound would make imports more expensive. Large firms with complex supply chains present ambiguity to valuation in the post-referendum environment.

This study contributes to our understanding of how GBP fluctuations affect complex firms and provides significant information to policymakers, firms, and investors about the impact on $F X$ exposures from Brexit. This study differs from other studies on the Brexit referendum as it focuses on $F X$ exposure.

First, we use the difference-in-differences (DID) method, which allows us to test explicitly for significant differences between the group of British firms and the groups of German and Spanish firms before and after the Brexit referendum.

Then, we estimate firm-level $F X$ exposures in three periods: the pre-referendum period (05/30/2014-06/17/2016), the post-referendum period (06/24/2016-07/20/2018), and the full sample period (05/30/2014-07/20/2018). We run time-series regressions of changes in $F X$ rates against the stock returns, controlling for market effects (see Jorion, 1990). We find that $F X$ exposure following the Brexit vote increases significantly (in absolute terms) for the 26 FTSE100 firms but not for the IBEX and DAX firms. This paper distinguishes between positive and negative exposure and explains the characteristics of good and bad news for British, Spanish, and German nonfinancial firms.

Market-level exposure is also studied. In the pre-referendum period, all three markets were significantly exposed to GBP/EUR at a $1 \%$ level of significance. The Brexit referendum has a significant effect on all three indexes, reducing the market exposure of the IBEX to the GBP/EUR exchange rate, making current exposures insignificant. It also reduces the market exposure of the DAX to the GBP/EUR exchange rate, currently at the $10 \%$ level. As expected, the most interesting case is the FTSE. The FTSE index was significantly positive exposed to GBP/EUR at a $1 \%$ level of significance in the pre-referendum period, whereas it is significantly negative exposed to GBP/EUR at the $1 \%$ level in the post-referendum period. Thus, its 
exposure changes from positive to negative, resulting in an insignificant FTSE exposure to the GPB/EUR exchange rate for the full sample period.

Our work seeks to uncover the channel of the impact the Brexit referendum has had by studying interaction effects among the market index, the currency, and the referendum. Thus, we can identify the firms for which systematic risk or $F X$ exposures increase after the referendum. The scenario that captures an interaction effect among the index, the currency, and the referendum for German firms highlights the fact that the impact of the referendum is nebulous, and that affects German firms in complex ways.

Finally, we study asymmetric models of $F X$ exposure for our nonfinancial firms in the FTSE100, IBEX35, and DAX30 and discuss the implications of our results for the strategy of British, Spanish, and German firms after the Brexit vote.

For model validation and robustness checks, our model passes the tests for stationarity, multicollinearity, and misspecification. Following Muller and Verschoor (2006), and Krapl (2017), we test for volatility clustering in exchange rates and find no clustering effect in the GBP/EUR rate. Finally, to consider cross-sectional dependence in the residuals of firms within the same country (see Williamson, 2001; and Allayannis and Ihrig, 2001), we redesign the structure of the error terms and determine that the majority of our findings remain valid.

In the next section, we review the relevant literature and formulate our research hypotheses. Section 3 provides our methodology. Section 4 presents the sample and summary statistics. Section 5 validates our model and offers the empirical results. Section 6 tests the robustness of the results, accounting for cross-sectional dependence in the residuals of firms within the same country. Section 7 discusses the implications for firm strategy. The final section concludes. 


\section{Related literature and hypothesis development}

This study is related to two strands of academic literature. The first is the recent but expanding literature on the impact of the Brexit referendum and the UK's actual exit from the EU on financial markets. The second is the literature on $F X$ exposure.

\subsection{Literature on the impact of the Brexit referendum}

In this section, we discuss the literature related to the Brexit referendum. The UK has been a member of the EU for over 20 years, an economic agreement that dictates the free movement of capital, labor, and goods among member countries. Changes to the UK's status will alter how UK firms will interact with EU member countries. Begg (2017) discusses how imports and exports from the UK are interlinked with EU firms and advises that Brexit will have an impact on the UK and the 27 other EU nations. The impact of the complexity for supply chains is reflected in the study by Erken et al. (2018) on the impact of Brexit with respect to import and export activities between UK firms and the EU.

Plakandaras et al., (2017) examine whether the sudden depreciation of the GBP relative to the USD is due to the reaction of market participants to Brexit or whether the result of the referendum has little impact on the USD/GBP $F X$ rate. They estimate linear and nonlinear econometric and machine learning models and evaluate out-of-sample forecasts of the $F X$ rate and its realized volatility in the pre- and post-Brexit periods. They quantify the uncertainty caused by the referendum using an index based on news related to economic uncertainty. They argue that with a daily forecasting horizon, their models adhere closely to the evolution of the observed $F X$ rate and that most of the depreciation is based on the uncertainty caused by Brexit.

Tielmann and Schiereck (2016) find an overall negative effect of the Brexit referendum on the value of European logistics companies. Schiereck et al., (2016) establish that the reaction of bank stock prices to the Brexit announcement was more severe than the reaction to the Lehman bankruptcy, but the response of the credit default swap market was far more subdued. 
Jackowicz et al., (2017) study price adjustments on the Warsaw Stock Exchange (WSE) following the Brexit vote. They find that prices of stocks in the WSE declined due to the referendum; however, the decline was not more severe for firms that are dependent on European markets or on export activities overall.

Dhingra et al., (2018) discuss the economic consequences of Brexit, arguing that lower trade due to reduced integration between the UK and the EU will significantly offset any benefits to the UK of not contributing to the EU budget.

Samitas et al., (2018) argue that the EU will suffer more economic damage than the UK. They employ an agent-based model and test for the short-term and long-term effects of Brexit on the financial stability of the EU and UK. They confirm predictions of other studies regarding the output cost of Brexit with emphasis on the EU and show that financial stability is a key issue, with the banking system suffering major losses on both sides of the English Channel, especially over the longer term. They suggest that policymakers should consider dynamic effects that may be caused by UK banks moving to the EU after Brexit. They conclude that if banks in the UK choose to relocate, the negative effects on the EU may be mitigated.

The conclusions of each study show how the economy at large is impacted through Brexit, but there is little firm-level analysis showing how the economic implications have affected individual firms. This empirical study provides further detail on whether $F X$ exposure of companies in the UK or European markets have been more affected by the referendum.

This study fills the gap in the literature by assessing the impacts on $F X$ exposure to the UK, German and Spanish nonfinancial firms. Oehler et al., (2017) analyze the abnormal returns on UK stocks after the referendum. They suggest there is a systematic impact on the value of stocks after the initial vote. More specifically, they examine whether firm-level internationalization helps to explain abnormal returns. They find that stocks of firms with a higher proportion of domestic sales realize more negative abnormal returns than stocks of firms 
with more sales abroad, i.e., a higher degree of international diversification. While firm-level internationalization induces abnormal returns on the trading day after the referendum, it has no relevant pricing effect in the following days.

Caporale et al., (2018) examine the effects of Brexit on uncertainty in European financial markets by applying long-memory techniques (both parametric and semi-parametric). They examine whether the Brexit referendum leads to any changes in the degree of persistence of the FTSE100 Implied Volatility Index (IVI) and the implied volatilities (IVs) of the GBP visà-vis the other main currencies traded in the $F X$ market, namely, the EUR, the USD, and the Japanese yen (JPY). They split their sample to compare the stochastic properties of the series under study before and after the referendum and find an increase in the degree of persistence in all cases except for the GBP/JPY, whose persistence declined after the Brexit referendum.

Regarding the long-term impact, Caporale et al., (2018) show that analysts generally suggest a higher long-term risk to the value of the GBP relative to other currencies based on the shock of the Brexit referendum. This predicted volatility of the GBP along with complex company structures produces significant exposure for MNCs that trade with the EU.

Based on the previous discussion, we develop the following main hypothesis about how the referendum affects stock returns of individual FTSE100 companies.

H1. There is a drop in stock returns after Brexit.

\subsection{Literature on foreign exchange exposure}

There is extensive literature on international finance analyzing the effects of changes in $F X$ rates on corporate cash flows and firm value (e.g., Dumas, 1978; Flood and Lessard, 1986; Jorion, 1990; Bartov and Bodnar, 1994; and Oxelheim and Wihlborg, 1995; He and Ng, 1998; Allayannis and Ofek, 2001; Williamson, 2001; Bodnar and Wong, 2003; Bartram and Karolyi, 2006; Priestley and Ødegaard, 2007; Bartram and Bodnar, 2012; Akay and Cifter, 2014) that rely on constant, linear and symmetric models. 
By studying firm- and market-level $F X$ exposure, Hutson and Laing (2014) suggest that complex business structures and revenue generation models are associated with higher $F X$ exposure. In the short term, the currency markets can react with an immediate devaluation of the GBP due to a political shock. Following the Brexit referendum, the GBP was devalued from 1.5 to 1.2 USD and the devaluation can have a positive or negative impact on firms depending on where and how they operate.

We posit the following hypotheses on how the referendum affects the $F X$ exposure at the individual firm and market levels.

H2. The foreign exchange exposure at firm and market levels increases after the referendum.

H3. The foreign exchange exposure at firm and market levels after the referendum is most severe for British firms.

We also try to uncover the channel of the impact of the Brexit referendum on investors' firm- and market-level returns. We study interaction effects between a given market index and the referendum, the currency and the referendum, and a combination of the index, the currency, and the referendum. Toward this end, we posit the following hypotheses.

H4a: The referendum negatively affects firm- and market- level returns.

H4b: The referendum increases in absolute value the index exposure at the firm level.

H4c: The Brexit vote increases in absolute value the exchange rate exposure at both firm and market levels.

H4d: The referendum increases in absolute value both the index and currency exposure, at the firm level.

The literature continues with asymmetric $F X$ cash flow exposures, discussing why they can be asymmetric. One reason is that there is a lag in a firm's decision to enter/exit a foreign market (see Section 2.2). The reason for this behavior is that market entry/exit costs are incurred by expanding/contracting operations in foreign markets. 
Asymmetric hedging behavior is another reason cash flows may be asymmetrically exposed to $F X$ shocks. The use of currency derivatives with asymmetric payouts, such as currency options, can result in asymmetric $F X$ exposures. $F X$ cash flow asymmetry can also result from managers altering the timing and size of financial hedges, even if these hedges have symmetric payouts. According to Bodnar et al., (1998), 50\% of firms periodically (and 10\% frequently) alter the timing and size of their $F X$ hedges to fit in their market view.

Another reason for asymmetry in $F X$ cash flow exposures is the use of $F X$ pass-through and its relationship to a firm's pricing-to-market strategy. When dealing with an appreciation in the USD, export firms have the choice to pass through the adverse effect of the change in the $F X$ rate onto their foreign customers by increasing prices denominated in the foreign currency.

Pass-through as an $F X$ hedging strategy is an important reason why corporate cash flows can be asymmetrically exposed to $F X$ shocks (Froot and Klemperer, 1989; Marston, 1990; Kanas, 1997; and Bodnar et al., 2002).

Krapl (2017) analyzes $F X$ cash flow and equity exposures of a sample of U.S. multinational firms. Focusing on asymmetry in $F X$ cash flow exposures to the direction and magnitude of $F X$ shocks, he finds that asymmetry persists in several alternative measures of $F X$ cash flow exposure. He argues that market-related factors, in addition to cash flow-based reasons need to be considered when exploring $F X$ equity exposure. He also emphasizes that models with asymmetric specifications detect more firms with significant $F X$ exposures.

Based on the previous discussion, we posit the following hypothesis regarding how the referendum affects the asymmetry of $F X$ exposure.

H5. The exchange rate exposure after the referendum is more asymmetric for British firms. 


\section{Methodology}

\subsection{Difference-in-differences}

We follow the Difference-in-differences technique of Card and Krueger (1994) to test our first hypothesis:

$$
\begin{array}{r}
R_{i, t}=a+\beta_{\text {Market }} R_{m, t}+\beta_{\text {currency }}\left(\frac{\Delta \mathrm{S}}{\mathrm{S}}\right)_{t}+\gamma_{1} \text { Brexit }+ \\
+\gamma_{2} \text { FTSEfirm }+\gamma_{3} \text { BrexitFTSEfirm }+u_{t}
\end{array}
$$

where the term $R_{m, t}$ is the return on the market index, which controls for market movements, $R_{i, t}$ is the common stock return of the $i^{t h}$ firm, and $\left(\frac{\Delta \mathrm{S}}{\mathrm{S}}\right)_{t}$ is the end-of-period $F X$ rate for a change in GBP/EUR as measured by the domestic price of the foreign currency. ${ }^{2}$ Thus, a positive $\left(\frac{\Delta \mathrm{S}}{\mathrm{S}}\right)_{t}$ denotes a domestic currency depreciation.

The Brexit dummy takes the value of one for the weeks after the Brexit referendum of 06/24/2016 and zero otherwise. The FTSEfirm dummy takes the value of one for firms that belong to the FTSE100 and zero otherwise. The interaction term is BrexitFTSEfirm, which captures the firms that are in the FTSE100 during the period after the referendum. We correct for autocorrelation and heteroscedasticity with the Newey-West procedure.

The interaction term is the difference-in-differences (DID) estimator. If we ignore the impacts of the market index and the currency, namely $\beta_{\text {Market }}=\beta_{\text {currency }}=0$, this is strictly, speaking, the method used by Card and Krueger (1994):

$R_{i, t}=a+\gamma_{1}$ Brexit $+\gamma_{2}$ FTSEfirm $+\gamma_{3}$ BrexitFTSEfirm $+u_{t}$

The difference-in-differences between the treatment and the control group is the DID estimator under Eq. (1a), while Eq. (1b) is Eq. (1) without the impact of Brexit in Eq. (1):

\footnotetext{
${ }^{2}$ The bilateral $F X$ rate, $S$, is the price of the foreign currency in units of the home currency of the exporting firm. (If the UK is the exporter and EUR is the currency of the foreign market, the $F X$ rate is GBP/EUR).
} 


$$
R_{i, t}=a+\beta_{\text {Market }} R_{m, t}+\beta_{\text {currency }}\left(\frac{\Delta \mathrm{S}}{\mathrm{S}}\right)_{t}+u_{t}
$$

We also modify Eq. (1) to account for negative and positive currency returns. More specifically, we consider the impact of the Brexit referendum:

$$
\begin{aligned}
R_{i, t}= & a+\beta_{\text {Market }} R_{m, t}+\beta_{\text {currency }}^{-}\left(\frac{\Delta \mathrm{S}}{\mathrm{S}}\right)_{t}^{-}+\beta_{\text {currency }}^{+}\left(\frac{\Delta \mathrm{S}}{\mathrm{S}}\right)_{t}^{+}+ \\
& +\gamma_{1} \text { Brexit }+\gamma_{2} \text { FTSEfirm }+\gamma_{3} \text { BrexitFTSEfirm }+u_{t}
\end{aligned}
$$

In Eq. (1'), currency returns are decomposed into negative and positive return vectors, $\left(\frac{\Delta \mathrm{S}}{\mathrm{S}}\right)_{t}^{-}=\max \left\{\left(\frac{\Delta \mathrm{S}}{\mathrm{S}}\right)_{t}, 0\right\}$ and $\left(\frac{\Delta \mathrm{S}}{\mathrm{S}}\right)_{t}^{+}=\min \left\{\left(\frac{\Delta \mathrm{S}}{\mathrm{S}}\right)_{t}, 0\right\}$. Thus, $\beta_{\text {currency }}^{-} / \beta_{\text {currency }}^{+}$measures changes in the company's stock return due to depreciation/appreciation in the GBP versus the EUR.

\subsection{Firm-level foreign exchange exposure}

We estimate the relationship between the simple return of a company versus the return of its index and currency. The constant linear model literature represents the exposure of the company to the market index and its currency. The regression is estimated using four years of weekly simple returns for each firm, for its related index and for its currency. Our method takes the shock caused by the Brexit vote in 2016 into account:

$$
R_{i, t}=a+\beta_{\text {Market }} R_{m, t}+\beta_{\text {currency }}\left(\frac{\Delta \mathrm{S}}{\mathrm{S}}\right)_{t}+\varepsilon_{t}(\text { Changes in stock prices; Jorion, 1990) }
$$

The difference between Eq. (1b) and Eq. (2) is that in Eq. (2), we run a time-series regression of the firm's return against the index return and the exchange rate return, while in Eq. (1b), we pool the data and run the returns of all firms against the market and changes in the exchange rates. 


\subsection{Analyzing asymmetry to the direction of foreign exchange rate changes}

To test for asymmetry in $F X$ exposures to the direction of $F X$ shocks, we follow Koutmos and Martin (2003) and Muller and Verschoor (2006) as follows:

$$
R_{i, t}=a+\beta_{\text {Market }} R_{m, t}+\beta_{\text {currency }}^{-}\left(\frac{\Delta \mathrm{S}}{\mathrm{S}}\right)_{t}^{-}+\beta_{\text {currency }}^{+}\left(\frac{\Delta \mathrm{S}}{\mathrm{S}}\right)_{t}^{+}+v_{t}
$$

The difference between Eq. (1') and Eq. (3) is that in Eq. (3), we run firm-by-firm regressions, while in Eq. (1'), we run the returns of all firms together against the market, the changes in the exchange rates, and the dummy variables.

\subsection{Market-level foreign exchange exposure}

We further estimate $F X$ exposure at the market level to assess whether the effect of the Brexit referendum is systematic or firm specific. We estimate the following equation:

$$
R_{m, t}=a+\beta_{m, \text { currency }}\left(\frac{\Delta \mathrm{S}}{\mathrm{S}}\right)_{t}+\varepsilon_{m, t}(\text { Changes in stock prices; Jorion, 1990) }
$$

where $\beta_{\text {m,currency }}$ measures market-level $F X$ exposure in GBP/EUR. Similarly, to test for asymmetry in $F X$ market exposures with respect to the direction of $F X$ shocks, we estimate the following equation.

$$
R_{m, t}=a_{m}+\beta_{m, \text { currency }}^{-}\left(\frac{\Delta \mathrm{S}}{\mathrm{S}}\right)_{t}^{-}+\beta_{m, \text { currency }}^{+}\left(\frac{\Delta \mathrm{S}}{\mathrm{S}}\right)_{t}^{+}+v_{m, t}
$$

\section{Sample and summary statistics}

This study comprises the nonfinancial companies in the FTSE100, IBEX $35,{ }^{3}$ and DAX30 indexes. Table 1 presents the number of firms and information regarding their scope and details on market capitalization to show the importance of the nonfinancial sector to each index (for further details please see Appendix A1).

\section{[Insert Table 1]}

\footnotetext{
${ }^{3}$ The IBEX was significantly affected by political events during the study period, including the Catalonian declaration of independence, which caused the IBEX to fall approximately $7 \%$ over one year.
} 
We compare stock returns for the 26 FTSE100 firms, 10 IBEX35 firms, and 17 DAX30 firms before and after the Brexit referendum. We have a total of 217 weekly observations for the period 05/30/2014-07/20/2018. We divide the sample into two equal time periods: the prereferendum period $(05 / 30 / 2014-06 / 17 / 2016)$ and the post-referendum period $(06 / 24 / 2016-$ 07/20/2018) with 108 weekly observations in each.

Table 2 reports summary statistics, skewness (S), kurtosis $(\mathrm{K})$ and p-values for Jarque-Bera tests for stock returns, market index returns and currency returns (GBP/EUR). ${ }^{4}$ All of the stock returns are leptokurtic, indicating a high probability of high-magnitude shocks. 12 out of 26 FTSE100, four out of 10 IBEX35, and 11 out of 17 DAX30 firms have negatively skewed returns.

\section{[Insert Table 2]}

The lowest average return in the entire sample is generated by Distribuidora Internacional de Alimentac (DIA), a firm in the IBEX35, at $-0.43 \%$, and the highest is from Evraz, a FTSE100 firm that averages a 1.07\% return. The lowest average return prior to the Brexit vote, shown in Panel B, is for a FTSE100 firm, Tesco $(-0.50 \%)$, and the highest is for a DAX30 firm, Covestro (1.27\%). Finally, the lowest average return after the Brexit vote, shown in Panel $\mathrm{C}$, is for DIA (-0.72\%), and the highest is for Evraz (1.07\%).

During the full sample period, the currency returns are negatively skewed, indicating that large negative shocks are more frequent than large positive shocks. However, during the two sub-periods, before and after the Brexit referendum, currency returns are positively skewed. Currency returns are leptokurtic during the full sample period and for the two sub-periods, before and after Brexit, indicating a high probability of high-magnitude shocks.

During the full sample period and the period before the referendum, index returns are negatively skewed. However, during the period after the referendum, index returns are mixed.

\footnotetext{
${ }^{4}$ The Jarque-Bera test statistic is for the null hypothesis that the dependent variable is normally distributed.
} 
Specifically, the FTSE returns are positively skewed, while returns for the other two indexes are negatively skewed.

For the full sample and for the post-referendum period, index returns are leptokurtic. During the period before the referendum, FTSE index returns are leptokurtic, while IBEX and DAX are platykurtic, indicating a higher probability of high-magnitude shocks in the British stock market compared to the German and Spanish stock markets during the pre-referendum period.

\section{Empirical results}

\subsection{Model validation}

Before making the estimations, the models must pass basic tests to meet key assumptions for regression models. More specifically, stationarity tests show that the stock returns, index returns and the GBP/EUR exchange rate are stationary. ${ }^{5}$ Since the time series are stationary, we can proceed with estimations using OLS. We use two diagnostics tests for multicollinearity. The first one is the variance inflation factor (VIF). The rule of thumb is that if the VIF is equal to or higher than four, there is a multicollinearity problem. The highest value of the VIF for our dataset is 1.20 , which is far below the threshold of four, so we are not concerned about multicollinearity. We also estimate the variance-covariance matrix of the fitted coefficients of the regression model. The rule of thumb is that if the pairwise correlation of the fitted coefficients has an absolute value equal or higher than $50 \%$, there is a multicollinearity problem. The highest value of the correlation coefficient is $48.03 \%$ (in absolute value) while the mean (median) value is $24.95 \%(26.92 \%)$ in absolute value. So, again we do not detect multicollinearity according to this test. ${ }^{6}$

\footnotetext{
${ }^{5}$ Results are available upon request.

${ }^{6}$ Results are available upon request.
} 
Following Dominguez and Tesar (2006), we are not interested in testing a specific version of the CAPM, nor are we testing whether exchange rate risk is priced. We use Eqs (1) - (3)' as a context for isolating the association between returns and exchange rates for a cross-section of firms. Hence, we do not study for omitted variable bias. We also conduct a Ramsey RESET test, and conclude that our models do not suffer from misspecification. ${ }^{7}$

Finally, we test for the volatility-clustering phenomenon in exchange rates. Following Muller and Verschoor (2006) and Krapl (2017), we use an Engle's Lagrange multiplier test to determine the presence of ARCH effects in exchange rates. Based on our dataset, there are no $\mathrm{ARCH}$ effects in the GBP/EUR exchange rate, so we can employ ordinary least squares estimation with Newey and West (1987) HAC robust standard errors.

\subsection{Difference-in-differences (DID) based on symmetric and asymmetric models}

To evaluate H1, we use the DID method. The results are given in Table 3.

\section{[Insert Table 3]}

Table 3 shows that for the regression of Eq. (1), the Brexit coefficient is negative and significant at a $1 \%$ significant level, which means that there is a decline in stock returns after the Brexit vote, supporting H1. The FTSEfirm coefficient (the treatment effect) is negative but insignificant, while the interaction term (the DID estimator), which captures the impact on firms in the FTSE100 during the period after the referendum, is positive and significant only at the $10 \%$ level.

If we ignore the impact of the market index and the currency, namely, if $\beta_{\text {Market }}=$ $\beta_{\text {currency }}=0$, then the treatment effect, the Brexit and the interaction term become insignificant as indicated in Eq. (1a) shown in Panel A of Table 3.

\footnotetext{
${ }^{7}$ Results are available upon request.
} 
Eq. (1b) pools all the firms together and determines the impact of the market and the currency on returns. Under this model, $F X$ exposure is insignificant, and the index is again significant. Panel B of Table 3 shows the average change in returns before and after the Brexit vote for the control group, which includes the 10 IBEX35 and the 17 DAX30 firms, and the treatment group, including of the 26 FTSE100 firms. The difference in the differences between the treatment and the control groups is the difference-in-differences estimator under the model given in Eq. (1).

When we account for negative and positive currency returns, the results remain the same, and the coefficients $\beta_{\text {currency }}^{-}, \beta_{\text {currency }}^{+}$in Eq. (1') are insignificant.

\subsection{The impact of Brexit on the FTSE100, IBEX35 and DAX30}

To evaluate $\mathrm{H} 2$ and $\mathrm{H} 3$, we first analyze $F X$ exposure based on symmetric models at a firm level. In Eq. (2), we conduct stock return regressions for each firm with respect to bilateral exchange rates $(B E R s)$ to measure $F X$ exposure in Eq. (2) using weekly data for the period 05/30/2014-07/20/2018. The coefficient $\beta_{\text {currency }}$ is adjusted for market movements. We correct for autocorrelation and heteroscedasticity using the Newey-West procedure.

Simple returns for all nonfinancial firms are correlated with the returns of their respective index. The different correlations to the index may be driven by domestic versus foreign manufacturing operations in the domestic market.

The results of the BER regressions show that 11 of the 26 FTSE100 firms (42.31\%) in the sample have a significant $F X$ exposure at least, at a $10 \%$ significant level as shown in Panel A of Table $4 .{ }^{8}$ Five $(19.23 \%)$ firms have positive exposures to GBP/EUR, and the other six (23.08\%) have negative exposures. An example of a negative exposure is Unilever (ULVR), which has a statistically significant (at $1 \%$ ) currency exposure of -0.38 . In contrast, Next

\footnotetext{
${ }^{8}$ Out of 26 FTSE100 firms in the sample, $26.92 \%$ have a significant $F X$ exposure at least at the 5\% level (results are available upon request).
} 
(NXT) has a statistically significant positive currency exposure of 0.75 . This finding indicates that when the GBP weakens, relative to the EUR, NXT's returns suffer, affecting its equity valuation.

Then, we study the periods before (Panel B of Table 4) and after the Brexit vote (Panel C of Table 4). Before the Brexit vote, only Smiths Group (SMIN) has a positive $F X$ exposure at a 5\% significant level among the 26 FTSE firms. After the Brexit vote, the situation changes radically, with seven (nine) firms, or $26.92 \%$ (34.62\%) out of the 26 FTSE firms have a significant $F X$ exposure at least at a 5\% (10\%) level. Six firms $(23.08 \%)$ have negative exposure to GBP/EUR, and the other three (11.54\%) have positive exposure.

Out of the 10 IBEX35 firms, only ITX is positively exposed to GBP/EUR at a $1 \%$ significance level for the full sample period (see Table 4). The same firm, ITX, is the only firm out of the 10 IBEX35 firms positively exposed to GBP/EUR at a 5\% level before the referendum. However, none of the 10 IBEX35 firms has significant exposure to GBP/EUR after the Brexit referendum. A positive exposure indicates that when the EUR strengthens, ITX returns weaken. However, after the referendum, the strengthening EUR does not affect ITX's returns.

Finally, out of the 17 DAX30 firms, only the Merck Group is positively exposed to GBP/EUR at a $10 \%$ significance level for the full sample period and at $1 \%$ before the referendum. After the Brexit referendum, only Siemens is positively exposed to GBP/EUR among the 17 DAX30 firms. These results offer statistical evidence in support of $\mathrm{H} 3$ at the firm level, since according to the results shown in Table 4, the number of British firms with significant exposure to the GBP/EUR increases after the referendum. However, these results do not support $\mathrm{H} 2$ at the firm level, since the numbers of DAX30 and IBEX35 firms exposed to GBP/EUR do not increase after the referendum.

\section{[Insert Table 4]}


We then move to evaluate $\mathrm{H} 2$ and $\mathrm{H} 3$, analyzing $F X$ exposure based on symmetric models at the market level. In Panel D of Table 4, we present the findings from estimating Eq. (2') to determine $F X$ exposures for each of our three national stock markets. For the full sample period, the DAX and IBEX are significantly exposed to GBP/EUR at a $1 \%$ level, while the FTSE is not exposed to GBP/EUR at standard significance levels. However, in the pre-referendum period, all three markets are significantly exposed to GBP/EUR at 1\%. The Brexit referendum has a significant effect on all the three indexes. After the Brexit referendum, the market exposures for both the IBEX and the DAX to GBP/EUR become insignificantly and significantly exposed at $10 \%$ respectively.

The most interesting case as expected, is the FTSE. While in the pre-referendum period, the FTSE is positively exposed to GBP/EUR at $1 \%$. In the post-referendum period, it is negatively exposed to GBP/EUR at $1 \%$. Since, its exposure changed from positive to negative, before and after the Brexit vote, the exposure coefficient of the FTSE for the full sample is insignificant.

Therefore, the Brexit vote leads to a reduction in the $F X$ rate exposure at the market level, not to an increase as $\mathrm{H} 2$ states. All the three markets' $F X$ exposures fall in absolute terms.

We note that while there is moderate exposure for the DAX and IBEX, there is significant exposure for the FTSE, supporting $\mathrm{H} 3$ at market level. This finding suggests that tariffs expected to be imposed post-Brexit could cause significant damage to export for UK nonfinancial firms, and revenues and consequently to the equity valuations of those companies. This result is inconsistent with Samitas et al., (2018) who claim that the German economy is affected more by the Brexit referendum, as the above analysis shows more exposure for the FTSE. Moreover, in Panel C of Table 6, after the Brexit vote, the number of the FTSE100 firms in the sample exposed to appreciations and depreciations in GBP/EUR increases from five to 
12 (46.15\%), confirming H3. Rolls-Royce (RR) and ULRV are exposed to both depreciation and appreciation of GBP/EUR.

\subsection{The impact of Brexit under different scenarios}

To evaluate H4, we start with $\mathrm{H} 4 \mathrm{a}$ which suggests that the Brexit referendum negatively affects firm- and market level- returns. In this scenario, we study the difference in stock returns before and after the referendum, holding the market index and currency returns constant. We add a Brexit dummy, $\gamma_{1}$ Brexit, in Eq. (2). If the dummy is positive, then stock returns are higher after the referendum than before (keeping other factors constant).

\section{[Insert Table 5]}

More firms are affected by Brexit in a negative way supporting H4a. Out of the 26 FTSE100 firms in the sample, $19.23 \%(34.62 \%)$ have a significant $F X$ exposure at least at the $5 \%(10 \%)$ level, as indicated in Table 5. Kingfisher PLC (KGF) and Coca-Cola HBC (CCH) go from exposed to unexposed, while all the other firms remain the same at the same level of significance. ${ }^{9}$ For the other three firms in the FTSE100, the impact of the Brexit vote is negative and significant at 5\%. Of the 10 IBEX35 firms, the impact of the Brexit referendum is significantly negative for ITX and SGRE at 5\%. Of the 17 DAX30 firms, no firm is significantly exposed to GBP/EUR. For Fresenius (FRE), the impact of the Brexit vote is negative at $5 \%$.

At the bottom of Table 5, we also present the $F X$ response coefficients for each of our three national stock markets. With respect to $\mathrm{H} 4 \mathrm{a}$, the DAX and IBEX are significantly exposed to GBP/EUR, while the FTSE is not.

We then evaluate $\mathrm{H} 4 \mathrm{~b}$, which states that the Brexit vote increases in absolute value the index exposure. At the firm level, we add a multiplicative dummy, $\gamma_{2}$ Brexit $_{m, t}$, to Eq. (2)

${ }^{9}$ Results are available upon request. 
that captures an interaction effect between the market index and the referendum, and the difference in index exposure before and after the referendum. H4b can also be read as "the vote increases in absolute terms, the systematic risk at the firm level". Five out of the 26 FTSE100 firms have a significant $F X$ exposure of at least at 5\% as shown in Table 5. Barratt and KGF go from exposed at a 5\% level to unexposed, while Smith and Nephew (SN) goes from exposed at a $5 \%$ level to exposed at a $1 \%$ level. ${ }^{10}$ The Brexit vote increases the systematic risk only for Smurfit Kappa Group (SKG).

Of the 10 IBEX35 firms in the sample, ITX and Viscofan have significant $F X$ exposures at $5 \%$, the same firms that have significant exposures in evaluating $\mathrm{H} 4 \mathrm{a}$, as indicated in Table 5. The Brexit referendum decreases the level of systematic risk only for SGRE, where the impact of the referendum is significantly negative at $5 \%$.

Of the 17 DAX30 firms, systematic risk for Siemens increases while that of HeidelbergCement (HEI) decreases due to the Brexit referendum, as indicated in Table 5.

In other words, $\mathrm{H} 4 \mathrm{~b}$ is supported by one firm at $5 \%$ and one at $10 \%$ from among the 26 FTSE100 firms, but not by any of the 10 IBEX35 firms and by only one out of the 17 DAX30 firms; hence, for the majority of firms, $\mathrm{H} 4 \mathrm{~b}$ is not supported.

H4b is not applicable for the three national stock markets, because in this case the market index is a dependent variable, not an independent variable.

To evaluate $\mathrm{H} 4 \mathrm{c}$, which postulates that the referendum increases $F X$ exposure at the firm level, we study the interaction effect between the currency and the referendum and the difference in $F X$ exposure before and after the referendum. In this scenario, we add a Brexit multiplicative dummy, $\gamma_{3}$ Brexit $\left(\frac{\Delta S}{S}\right)_{t}$, into Eq. (2). Out of the 26 FTSE100 firms in the sample, SMIN has a significant $F X$ exposure at $5 \%$ and two firms at $10 \%$. All other firms

\footnotetext{
${ }^{10}$ Results are available upon request.
} 
become insignificant. Of the 10 IBEX35 firms in the sample, only ITX has a significant $F X$ exposure at $10 \%$. Of the 17 DAX30 firms in the sample, Merck has a significantly positive $F X$ exposure at 5\%. These findings are shown in Table 5. In other words, $\mathrm{H} 4 \mathrm{c}$ is supported by three out of the 26 FTSE100 firms, by one out of the 10 IBEX35 firms and by one out of the 17 DAX30 firms; therefore, for the majority of firms, H4c is not supported.

The Brexit referendum increases the $F X$ exposure of Associate British Foods (ABF) and Siemens, based on the fact that the impact of the Brexit referendum is significantly positive at $5 \%$. We do not have statistical evidence that the Brexit referendum increases or decreases the $F X$ exposure of any of the 10 IBEX35 firms.

We also evaluate $\mathrm{H} 4 \mathrm{c}$ at the market level. All three market indexes are positively exposed to GBP/EUR at $1 \%$. Moreover, the Brexit referendum significantly (at the $1 \%$ level) decreases the $F X$ exposure of all three markets, which is against $\mathrm{H} 4 \mathrm{c}$ at the market level.

Finally, using interaction terms, we evaluate $\mathrm{H} 4 \mathrm{~d}$, that postulates that the referendum increases in absolute value both the index and currency exposure at the firm level. We add two Brexit multiplicative dummies $\delta_{2}$ Brexit $_{m, t}+\delta_{3}$ Brexit $\left(\frac{\Delta \mathrm{S}}{\mathrm{S}}\right)_{t}$ into Eq. (2). Out of 53 firms, only SMIN, Merck, and ITX have positive $F X$ exposures, and SN and HEI have negative $F X$ exposures. The Brexit referendum increases (decreases) the systematic risk only for SKG (SGRE) and increases the $F X$ exposure of $\mathrm{ABF} .{ }^{11}$ It also decreases the $F X$ exposures of Mondi and Croda. The Brexit vote does not affected the $F X$ exposure of the 10 IBEX35 firms. Of the 17 DAX30 firms, only Siemens (HEI) is positively (negatively) affected through the index at $5 \%$ level of significance.

\footnotetext{
${ }^{11}$ Results are available upon request.
} 
The final case, (H4d) captures interaction effects among the index, currency, and the referendum. We find more German firms affected by Brexit with a significant $F X$ exposure. In other words, H4d is supported only for German firms.

In determining the $F X$ response coefficients for each of the three national stock markets under the fourth scenario $(\mathrm{H} 4 \mathrm{~d})$, this scenario is not applicable because now the market index is the dependent variable, not an independent variable.

\subsection{Asymmetry in the direction of the foreign exchange exposure shocks}

In this section, we evaluate H5. Table 6 reports $F X$ exposures estimated using Eq. (3) and presents the statistical significance of $F X$ exposure asymmetries.

\section{[Insert Table 6]}

When we decompose currency returns into negative and positive returns, the BER regressions show that two (five) out of the 26 FTSE100 firms, namely, $7.69 \%$ (19.23\%) are exposed to appreciations of the GBP/EUR at a confidence level of at least at 5\% (10\%). In addition, $\mathrm{SN}$ and $\mathrm{KGF}$ have significant $F X$ exposure to a depreciation of the GBP/EUR at a 5\% level and DEO at 10\%. Eight firms out of $26(30.77 \%)$ are significant at least at $10 \%$ as shown in Panel A of Table 6. Four firms are exposed to changes in the GBP/EUR but not to deprecations or appreciations of GBP/EUR. In contrast, Tesco is negatively exposed to appreciations in the GBP/EUR (at 10\%) but not to changes in GBP/EUR. ${ }^{12}$ This percentage is similar to the percentage from the symmetric model ( 11 out of 26 firms); therefore, the evidence does not support H5.

Out of the 10 IBEX35 firms, only ITX and Viscofan have significantly positive $F X$ exposures at $1 \%$ respectively due to depreciation and appreciation of GBP/EUR. The same firms are also exposed to changes in GBP/EUR. Thus, we do not have evidence to support H5.

\footnotetext{
${ }^{12}$ Results are available upon request.
} 
Finally, out of the 17 DAX30 firms, three are exposed to appreciations in the GBP/EUR rate and two to depreciation, but none of these firms are exposed to changes of GBP/EUR.

Then, we analyze $F X$ exposure asymmetry as to the direction of $F X$ shocks before the Brexit vote (Table 6, Panel B). KGF and SMIN have significantly negative and positive $F X$ exposures at 5\%, respectively, due to appreciation in the GBP/EUR. NXT has a positive exposure at $10 \%$ to appreciations of GBP/EUR. KGF and RR have significantly positive and negative $F X$ exposures at 5\%, respectively, to depreciations in GBP/EUR. Finally, SN has a significantly negative $F X$ exposure to the depreciation in the GBP/EUR at $10 \%$, as indicated in Table 6 (Panel B). It is a total of five (19.23\%) out of the 26 FTSE100 firms. Interestingly, KGF, a British retailing MNC and the third largest commercial property developer in the UK, is exposed to both depreciation and appreciation in the GBP/EUR.

A total of four out of the 10 IBEX35 firms are exposed to depreciation of GBP/EUR, while no Spanish firm is exposed to appreciations of GBP/EUR. Finally, two out of the 17 DAX30 firms have $F X$ exposure to depreciation in GBP/EUR, and only BMW has a significantly positive $F X$ exposure at $5 \%$ to appreciations in GBP/EUR. It is a total of three firms $(17.65 \%)$ out of the 17 DAX30 firms (Table 6, Panel B).

After the Brexit vote, the firm numbers exposed to GBP/EUR change considerably. For the FTSE100, three firms are exposed before and after the referendum. KGF and SMIN are exposed before but not after the referendum. However, most firms become exposed after the referendum. Moreover, RR and $\mathrm{SN}$ were exposed before the referendum, but their exposures are intensified after the referendum. NXT was exposed to appreciation of GBP/EUR before the referendum but becomes exposed to depreciation after the referendum.

On the other hand, out of the 10 IBEX35 firms, only FER/Viscofan has a negative/positive exposure to depreciation/appreciation of GBP/EUR at a 5\% level of significance after the referendum, in contrast to the exposure of four out of the 10 IBEX35 firms (40\%) before the 
referendum, supporting our H3. Moreover, none of the Spanish firms that were exposed to GBP/EUR before the Brexit vote, that is, ITX, Grifols, Acerinox, and CIE, is exposed after the referendum.

The number of German firms, exposed to appreciation and depreciation in the GBP/EUR increases from three to five out of $17(29.41 \%)$, which is contrary to H5. Moreover, Linde and Continental have positive exposure at $1 \%$ and $5 \%$, respectively, to appreciation in the GBP/EUR. Siemens and Linde have positive and negative exposures, respectively, at 5\% to depreciation in the GBP/EUR. Linde is exposed to both depreciation and appreciation in the GBP/EUR.

However, compared to German firms, more British firms in percentage terms, are exposed to GBP/EUR after the Brexit vote but we notice more $F X$ exposures during GBP/EUR appreciations than GBP/EUR depreciations only for German firms (Table 6, Panel C), which is consistent with previous studies (see Koutmos and Martin, 2003; Muller and Verschoor, 2006; Krapl, 2017). These asymmetric $F X$ exposures of German firms is consistent with the argument that $F X$ exposure reflects a lag in the reactions of firms with respect to their exit/entry decisions, which is documented in the literature (Baldwin and Krugman, 1989; Baldwin, 1990; Ljungqvist, 1994). More specifically, the result is attributed to exit decisions and market exit costs incurred by German firms leaving the UK. Another reason for this result is that the managers of German firms alter the timing and size of their financial hedges to fit in their market views.

This asymmetric behavior is also consistent with the impact of the Brexit referendum and Brexit on financial markets literature. More specifically, Davies and Studnicka (2018) study how news of Brexit affects expectations through stock returns. They show that while most firms had negative returns following the referendum, there was substantial heterogeneity in their changes relative to expectations. They argue that this heterogeneity is explained by the 
firm's global value chain, with firms heavily exposed to the EU and UK doing worse than firms that are less heavily exposed.

Table 6 (Panel D) presents the findings from estimating Eq. (3') to determine the $F X$ response coefficients for each of our three national stock markets for different time periods. In the full sample period, the DAX and the IBEX have positive exposures to depreciations in the GBP/EUR at $1 \%$, and the DAX is also positively exposed to appreciations in the GBP/EUR at $5 \%$. The FTSE is exposed to neither appreciations nor depreciations in GBP/EUR at standard levels. In the pre-referendum period, all three markets were significantly positive exposed to GBP/EUR appreciation and depreciation at standard levels (Table 6, Panel D).

The Brexit referendum appears to have a significant effect on all the three indexes. After the Brexit vote, the IBEX is not significantly exposed to GBP/EUR in its appreciations or its depreciations and the DAX is positively exposed only to the depreciation in GBP/EUR at $10 \%$. However, again, the most interesting case is the FTSE which is significantly negative exposed to appreciations of GBP/EUR at 5\%. Therefore, the Brexit vote leads to a change in asymmetric exposure to $F X$ rate changes at the market level.

\section{Robustness checks}

We test the robustness of our results by considering the seemingly unrelated regressions (SUR) method proposed by Zellner (1962). The SUR method has been used by Williamson (2001) to analyze exchange rate exposure and competition in the automobile industry. Williamson (2001) uses SUR to account for cross-sectional dependence in the residuals of firms within the same country. Allayannis and Ihrig (2001) also estimate their regression equation using SUR for their sample of U.S. manufacturing industries to account for the crossequation correlations in the error terms.

Similar to Williamson (2001), we use the SUR method for cross-sectional dependence in the residuals of firms within the same index. The SUR results are summarized and contrasted 
with the base case scenario results in Appendix A2, Table A2. We employ the Breusch-Pagan (BP) test for error independence, which detects statistically significant cross-sectional correlations between the errors in the return equations for each index. ${ }^{13}$ We conclude that there is a statistically significant correlation between the errors in the return equations of the group of the 26 FTSE100 firms, the group of the 10 IBEX35 firms and the group of 17 DAX30 firms for the full sample period, the pre-referendum period and the post-referendum period, used to estimate Eq. (2) and Eq. (3), or when we add dummy variables to Eq. (2) to study H4a-H4d.

To test the robustness of $\mathrm{H} 2$ and $\mathrm{H} 3$, we estimate Eq. (2) for the full sample, pre-referendum and post-referendum periods, using the SUR method. ${ }^{14}$

For the full sample, the results of the BER regressions show that 12 of $26(46.16 \%)$ FTSE100 firms have a significant $F X$ exposure at least at $10 \%$, compared to $11(42.31 \%)$ in the base case scenario, as indicated in Panel A of Table A2. ${ }^{15}$ Five $(19.23 \%)$ of these firms have positive exposures to GBP/EUR, and the other seven (26.93\%) have negative exposures, compared to five and six, respectively, in the base case scenario. So, the results are very similar to the base case scenario.

The results are the same for the 26 FTSE firms as in the base case scenario prior to the Brexit vote, while after the Brexit vote the results are similar to the base case scenario as shown in Panel A of Table A2.

For the 10 IBEX35 firms, the results using the SUR method are similar to the base case scenario for the full sample period, the pre-referendum period and the post-referendum period (see Table A2). Finally, for the 17 DAX30 firms under the SUR estimation, one firm is positively exposed at a $5 \%$ level of significance and two firms at $10 \%$ in the full sample period,

\footnotetext{
${ }^{13}$ Results are available upon request.

${ }^{14}$ As in the base case scenario, simple returns for the nonfinancial index components are correlated to the returns of the index.

${ }^{15}$ Out of 26 FTSE100 firms, $34.62 \%$ have a significant $F X$ exposure at least at the $5 \%$ level (results are available upon request).
} 
while in the base case scenario only Merck Group is significant at the $10 \%$ level. Before the vote, the results remain the same as in the base case scenario. After the Brexit vote, for the 17 DAX30 firms under the SUR estimation, two firms are positively exposed at a 5\% level of significance and one at $10 \%$.

Hence, our results regarding the hypotheses $\mathrm{H} 2$ and $\mathrm{H} 3$ are robust to the SUR estimation, since, as shown in Table A2, after the referendum, the number of Spanish and German firms exposed to GBP/EUR does not increase but the number of British firms exposed to GBP/EUR does increase. The SUR estimation confirms the base case scenario results and hence supports hypothesis $\mathrm{H} 3$ but not $\mathrm{H} 2$ at the firm level.

We then test the robustness of $\mathrm{H} 4 \mathrm{a}-\mathrm{H} 4 \mathrm{~d}$ allowing for cross-sectional dependence in residuals of firms within the same index. We conclude that there is a statistically significant correlation between the errors in the return equations for the group of the 26 FTSE100 firms, the group of the 10 IBEX35 firms and the group of the 17 DAX30 firms under all four models. First, for the case of H4a, out of the 26 FTSE100 firms, $30.76 \%(34.62 \%)$ have a significant FX exposure at a 5\% (10\%) confidence level as indicated in Panel B of Table A2, compared with $19.23 \%$ (34.62\%) in the base case scenario. Hence, the number of firms exposed to the $10 \%$ level remains the same while the number of firms exposed at $5 \%$ level increases. The SUR estimation confirms the base case scenario results and therefore we confirm H4a. For the IBEX, the results under the SUR estimation are the same as under the base case scenario. For the DAX firms, there is only one difference that under the base case scenario of the 17 DAX30 firms, no firm is exposed to GBP/EUR while under the SUR estimation, Merck is positively exposed at a 10\% level of significance. The impact of Brexit is the same for the 26 FTSE100, 10 IBEX35, and 17 DAX30 firms under the SUR estimation as it is under the base case scenario.

When we test the robustness of $\mathrm{H} 4 \mathrm{~b}$ at the firm level, the only difference is that under the SUR estimation, two more firms are positively exposed at the 5\% level, as shown in Panel B 
of Table A2. The Brexit vote increases systematic risk for the same firms as in the base case scenario. The results regarding H4b, under the SUR estimation, are identical to the base case scenario results for the 10 IBEX35 firms and 17 DAX30 firms. Hence, the SUR estimation confirms the base case scenario results: for the majority of firms, H4b is not supported.

We then test the robustness of H4c. Out of the 26 FTSE100 firms, the only difference is that under the SUR estimation one additional firm has a significantly positive $F X$ exposure at $5 \%$, while it is unexposed under the base case scenario. The impact of Brexit under the SUR estimation is similar as under the base case scenario.

Regarding H4c, the results under the SUR estimation are similar to the base case scenario results for the 10 IBEX35 firms and the 17 DAX30 firms. The only difference is that under the SUR estimation only ITX among the 10 IBEX35 firms has a significant $F X$ exposure at the 5\% confidence level and Merck (a DAX firm) has a significantly positive $F X$ exposure at $1 \%$ as compared to the $5 \%$ level in the base case scenario. These findings are shown in Table A2. The Brexit vote increases the $F X$ exposure of $\mathrm{ABF}$ and Siemens since the impact of the referendum is significantly positive at $5 \%$. We do not have statistical evidence that the Brexit vote increases or decreases the $F X$ exposure of any of the 10 IBEX35 firms; as in the base case scenario for the majority of firms, $\mathrm{H} 4 \mathrm{c}$ is not supported.

Then, we test the robustness of $\mathrm{H} 4 \mathrm{~d}$, which captures interaction effects among the index, the currency, and the referendum. More German firms are affected by Brexit with a significant $F X$ exposure under the SUR estimation compared to the base case scenario. H4d is supported only for German firms.

Finally, we test the robustness of H5 using the SUR method to estimate Eq. (3) for the full sample, and for the pre-referendum and post-referendum periods. The BER regressions using the SUR method show that five (six) out of 26 FTSE100 firms, namely, 19.23\% (23.07\%), are exposed to appreciations in the GBP/EUR exchange rate at a significance level of at least 5\% 
(10\%), compared to two (five) firms under the base case scenario. Hence, the SUR method detected more FTSE100 firms with asymmetric exchange rate exposure compared to the base case scenario.

A total of 10 out of the 26 FTSE100 firms (38.46\%) are significantly exposed to either appreciation or depreciation in the GBP/EUR rate at a significance level of at least $10 \%$ as illustrated in Panel B of Table A2, compared to eight firms in the base case scenario. Three firms are exposed to changes in GBP/EUR but not to depreciations or appreciation only, and they are the same as in the base case scenario. This percentage is comparable to the percentage from the symmetric model (12 out of 26 firms), so H5 is not supported. Therefore, we reach the same qualitative result with the SUR estimation method as with the base case scenario for the British firms, and hence we conclude that our result is robust.

For the 10 IBEX35 firms, we reach the same qualitative results with the SUR estimation method as in the base case scenario, as shown in Panel C of Table A2. Therefore, our result is robust.

Finally, out of the 17 DAX30 firms, three are exposed to appreciation in the GBP/EUR rate and one is exposed to depreciation, but none of these firms are exposed to changes of GBP/EUR, as in the base case scenario.

Then, we analyze $F X$ exposure asymmetry to the direction of $F X$ shocks before the Brexit vote (Table A2, Panel C). A total of four firms out of the 26 FTSE100 firms $(15.38 \%)$ are exposed, compared to five firms in the base case scenario. So, the results under the SUR estimation are similar to those under the base case scenario. For the 10 IBEX35 firms and the 17 DAX30 firms, the results regarding $F X$ exposure asymmetry to the direction of $F X$ shocks prior to the Brexit vote under the SUR estimation are identical to the base case scenario results (Table A2, Panel B). Hence, the results for pre-referendum are robust. 
After the Brexit vote (Table A2, Panel C), for the 26 FTSE100 firms and the 10 IBEX35 firms, we reach the same qualitative results with the SUR estimation method as in the base case scenario. For German firms, after the Brexit vote, the qualitative results are similar under SUR estimation to the base case scenario results. Hence, we confirm that the $F X$ exposure after the referendum is more asymmetric for German firms under the SUR estimation. Again, we note greater $F X$ exposure during GBP/EUR appreciation than depreciation only for German firms.

\section{Implications for firm strategy}

Our focus is to understand the impact of the Brexit referendum on individual firm-level and market-level $F X$ exposures of a sample of 26 FTSE100, 10 IBEX35, and 17 DAX30 nonfinancial firms. Towards this reason, we provide a battery of statistical tests. In this section, we discuss the implications of this study for firm strategy.

The implications for firm strategy can be categorized based on each statistical test. Starting with the DID method, we show that the Brexit vote has a positive impact on FTSE100 nonfinancial firms relative to the firms in the control group (DAX30 and the IBEX35 firms). Thus, an event such as Brexit affects exchange rates in a negative manner but stock markets in a positive manner, supporting our $\mathrm{H} 1$ at the firm level.

To study firm-level and market-level $F X$ exposures, we use symmetric models. After the Brexit referendum, the number of FTSE100 firms with significant exposure to GBP/EUR increased from one to nine. So, an event such as the Brexit vote must be an alert to UK firms to use more currency derivatives and other methods to hedge currency exposures, supporting $\mathrm{H} 3$ at the firm level. However, firms in other EU markets (DAX30 and IBEX35 firms) should not be concerned to the same extent given that the referendum significantly affected British nonfinancial firms but had no significant impact on Spanish or German nonfinancial firms, as $\mathrm{H} 2$ states. 
Then, we study market-level $F X$ exposure using symmetric models. Firms and investors should expect that stock markets will move after events such as Brexit. The Brexit referendum leads to a reduction in $F X$ rate exposure at the market level, not to an increase as $\mathrm{H} 2$ states. Our results support our hypothesis $(\mathrm{H} 3)$ that $F X$ exposure at the market level after the referendum is most severe for the British firms. All three markets' $F X$ exposures fall in absolute terms, but FTSE is the most interesting case.

Our third methodology captures interaction effects among the index, the currency and the referendum for German firms, highlighting the fact that the vote is a nebulous event that affects German firms in a complex manner, implying that events such as Brexit should not be downgraded in other countries.

The fourth statistical test studies firm and market-level $F X$ exposures using asymmetric models. We decompose currency returns into negative and positive returns. After Brexit, the number of German firms exposed to appreciation or depreciation in the GBP/EUR rate increases, in contrast to our hypothesis (H5) that after the referendum exposure would be most asymmetric for British firms. Still, as a percentage there are more British firms exposed to GBP/EUR after the Brexit vote compared to German firms.

\section{Conclusions}

We analyze the reaction of the foreign exchange exposures of 26 FTSE100, 10 IBEX35, and 17 DAX35 nonfinancial firms to the Brexit announcement by collecting 217 weekly observations for the period 05/30/2014-07/20/2018. We divide the sample into two equal time periods: pre-referendum (05/30/2014-06/17/2016) and post-referendum (06/24/201607/20/2018) with 108 weekly observations each. We use four different statistical tests to evaluate our research hypotheses (the difference-in-differences method; firm and market-level $F X$ exposure using symmetric and asymmetric models; interaction effects among the index, the currency and the referendum; firm and market-level $F X$ exposure using asymmetric models). 
Our models passed tests for stationarity, multicollinearity, and misspecification. We also test for volatility clustering in exchange rates and do not find any clustering effects. Accounting for cross-sectional dependence in the residuals of firms within the same country, the majority of our findings still hold.

We find the referendum has a positive and significant impact on the returns of the FTSE100 firms. We also find that following the Brexit vote, firm-level $F X$ exposures increase significantly (in absolute terms) for the 26 FTSE100 firms, but is not the case for the IBEX and DAX firms. Moreover, the Brexit vote leads to a reduction in exchange rate exposure at the market level. We highlight that models with asymmetric specifications detect more German firms with significant $F X$ exposures. This finding is attributed either to the market exit costs that German firms would have to incur to leave the UK, or to the possibility that managers of German firms alter the timing and size of financial hedges to fit their market views. Identifying the reason could be the focus of a further study.

\section{References}

Akay, G. H. and Cifter., A. (2014). Exchange Rate Exposure at the Firm and Industry Levels: Evidence from Turkey. Economic Modelling, 43, 426-434.

Allayannis, G., and Ihrig, J. (2001). Exposure and markups. Review of Financial Studies, 14, $805-835$.

Allayannis, Y. and Ofek., E. (2001). Exchange rate exposure, hedging, and the use of foreign currency derivatives. Journal of International Money and Finance, 20, 273-296.

Baldwin, R. (1990). Hysteresis in trade. Empirical Economics, 15, 127-142.

Baldwin, R. and Krugman, P. (1989). Persistent trade effects of large exchange rate shocks. Quarterly Journal of Economics, 104, 635-654.

Bartov, E. and Bodnar, G. M. (1994). Firm valuation, earnings expectations, and the exchange rate exposure effect. Journal of Finance, 44, 1755-1785.

Bartram, S. M. and Bodnar, G. M. (2012). Crossing the lines: The conditional relation between exchange rate exposure and stock returns in emerging and developed markets. Journal of International Money and Finance, 31, 766-792. 
Bartram, S. M. and Karolyi, G. A. (2006). The impact of the introduction of the Euro on foreign exchange rate risk exposures. Journal of Empirical Finance, 13, 519-549.

Begg, I. (2017). Making Sense of the Costs and Benefits of Brexit: Challenges for Economists. Atlantic Economic Journal, 45, 299-315.

Bodnar, G, M. and Wong, M. H. F. (2003). Estimating exchange rate exposures: some 'weighty' issues. Financial Management, 32, 35-68.

Bodnar, G. M., Dumas, B. and Marston, R. C. (2002). Pass-through and Exposure. Journal of Finance, 57, 199-231.

Bodnar, G. M., Hayt, G. S. and Marston, R. C. (1998). Wharton survey of financial risk management by US non-financial firms. Financial Management, 24, 70-91.

Caporale, G., Luis., G. M. and Tommaso, T. (2018). Brexit and Uncertainty in Financial Markets. International Journal of Financial Studies, 6, 1-9.

Card, D. and Krueger, A. (1994). Minimum Wages and Employment: A Case Study of the Fast-Food Industry in New Jersey and Pennsylvania. American Economic Review, 84, $772-784$.

Davies, R. B. and Studnicka., Z. (2018). The Heterogeneous Impact of Brexit: Early Indications from the FTSE. European Economic Review, 110, 1-17.

Department for International Trade (February 2019). UK Trade in Numbers, $1-44$.

Dhingra, S., Ottaviano, G., Sampson, T. and Reenen, J. V. (2016). The consequences of Brexit for UK trade and living standards. CEP BREXIT Analysis No.2, CEPBREXIT02. London School of Economics and Political Science, CEP, London, UK.

Dhingra, S., Ottaviano, G., Rappoport,V., Sampson, T. and Thomas, C. (2018). UK trade and FDI: A post-Brexit perspective. Papers in Regional Science, 97, 9-24.

Dominguez, K., and Tesar, L. (2006). Exchange rate exposure. Journal of International Economics, 68, 188-218.

Dumas, B. (1978). The Theory of the trading firm revisited. Journal of Finance, 33, 1019-1029.

Erken, H., Hayat, R., Prins, C., Heijmerikx, M. and De Vreede, I. (2018). Measuring the Permanent Cost of Brexit. National Institute Economic Review, 244, 46-55.

Financial Times. (2018). Why German industry should fear a no-deal Brexit. Financial Times Ltd $2018 \quad$ https://www.ft.com/content/c06b1762-761d-11e8-b326-75a27d27ea5f Accessed Aug 2018.

Flood, E. and Lessard., D. (1986). On the measurement of operating exposure to exchange rates. Financial Management, 15, 25-36. 
Froot, K. A. and Klemperer., P. (1989). Exchange rate pass-through when market share matters. American Economic Review, 79, 637-654.

Griffin, J. and Stulz., R. (2001). International competition and exchange rate shocks: a crosscountry industry analysis of stock returns. Review of Financial Studies, 14, 215-241.

He, J. and Ng, L. K. (1998). The foreign exchange exposure of Japanese multinational firms. Journal of Finance, 53, 733-754.

Hutson, E. and Laing, E. (2014). Foreign exchange exposure and multinationality' Journal of Banking and Finance, 43, 97-113.

Jackowicz, K., Kozłowski, L. and Podgórski., B. (2017). The distant echo of Brexit: Did exporters suffer the most? Finance Research Letters, 21, 132-139.

Jorion, P. (1990). The exchange rate exposure of U.S. multinationals. Journal of Business, 63, 331-345.

Kanas, A. (1997). Is economic exposure asymmetric between long-run depreciations and appreciations? Testing using cointegration analysis. Journal of Multinational Financial Management, 7, 27-42.

Koutmos, G. and Martin, A. D. (2003). Asymmetric exchange rate exposure: theory and evidence. Journal of International Money and Finance, 22, 365-383.

Krapl, A. A. (2017). Asymmetric foreign exchange cash flow exposure: A firm-level analysis. Journal of Corporate Finance, 44, 48-72.

Ljungqvist, L. (1994). Hysteresis in international trade: a general equilibrium analysis. Journal of International Money and Finance, 13, 387-399.

Marston, R. C. (1990). Pricing to market in Japanese manufacturing. Journal of International Economics, 29, 217-236.

Muller, A. and Verschoor, W. F. (2006). Asymmetric foreign exchange risk exposure: evidence from US multinational firms. Journal of Empirical Finance, 13, 495-518.

Oehler, A., Horn, M. and Wendt, S. (2017). Brexit: Short-term stock price effects and the impact of firm-level internalization. Finance Research Letters, 22, 175-181.

Oxelheim, L. and Wihlborg, C. G. (1995). Measuring macroeconomic exposure: the case of Volvo cars. European Financial Management 1, 241-263.

Plakandaras, V., Gupta, R. and Wohar, M. E. (2017). The Effects of Brexit on the Pound: Towards a Currency Crisis? Available at SSRN 3006489.

Priestley, R. and Ødegaard, B. A. (2007). Linear and nonlinear exchange rate exposure. Journal of International Money and Finance, 26, 1016-1037. 
Rhodes, C. (2018). Manufacturing: statistics and policy. Briefing Paper, House of Commons Library, Number 01942.

Samitas, A., Polyzos, S. and Siriopoulos, C. (2018). Brexit and Financial Stability: An Agentbased simulation. Economic Modelling, 69, 181-192.

Schiereck, D., Kiesel, F. and Kolaric, S. (2016). Brexit: (Not) another Lehman moment for banks? Finance Research Letters, 19, 291-297.

Tielmann, A. and Schiereck, D. (2016). Arising borders and the value of logistic companies: Evidence from the Brexit referendum in Great Britain. Finance Research Letters, 20, 2228.

Williamson, R. (2001). Exchange rate exposure and competition: evidence from the automotive industry. Journal of Financial Economics, 59, 441-475.

Zellner, A. (1962). An efficient method of estimating seemingly unrelated regression equations and tests for aggregation bias. Journal of the American Statistical Association. 57, 348368. 
Table 1.

Number of firms in sample.

\begin{tabular}{cccc}
\hline \multicolumn{5}{c}{ Panel A: Number of firms in sample and market capitalizations. } & \\
\hline Index & Number of Companies & Percentage of Companies \% & Market Capitalization \% \\
\hline FTSE & $\mathbf{1 0 1}$ & & \\
Non-financial & 26 & $26 \%$ & $31 \%$ \\
Financial & 75 & $74 \%$ & $69 \%$ \\
IBEX & $\mathbf{3 5}$ & $29 \%$ & $21 \%$ \\
Non-financial & 10 & $71 \%$ & $79 \%$ \\
Financial & 25 & & \\
DAX & $\mathbf{3 0}$ & $57 \%$ & $58 \%$ \\
Non-financial & 17 & $43 \%$ & $42 \%$ \\
Financial & 13 & & \\
\hline Total & $\mathbf{1 6 6}$ & & Germany \\
\hline Panel B: Number of Listed Companies & UK & 595 \\
\hline & Spain & 1858 & 555 \\
\hline 2014 & 3419 & 2398 & 531 \\
2015 & 3623 & 2307 & 450 \\
2016 & 3480 & 2053 & 465 \\
2017 & 3110 & 2089 & \\
2018 & 2979 & &
\end{tabular}

Table 2.

Summary statistics. The second column of Panel A offers the industry that each firm belongs.

\begin{tabular}{lccccccccc}
\hline \multicolumn{1}{c}{ Panel A: Full Sample period } & & & & & & \\
\hline Index & Industry & Company & $\mathrm{N}$ & Mean & Median & SD & S & K & $\begin{array}{c}\text { p-Value } \\
\text { JB }\end{array}$ \\
\hline \multirow{2}{*}{ FTSE } & Tobacco & BAT & 217 & 0.0010 & 0.0037 & 0.0295 & -0.1350 & 4.8100 & 0.0000 \\
& & & & & & & & & \\
FTSE & Pharma. & GSK & 217 & 0.0001 & -0.0004 & 0.0254 & -0.4007 & 4.6472 & 0.0000 \\
& & & & & & & & & \\
FTSE & Pharma. & AZN & 217 & 0.0017 & 0.0016 & 0.0323 & 0.1747 & 5.4496 & 0.0000 \\
FTSE & Beverages & DEO & 217 & 0.0022 & 0.0022 & 0.0247 & 0.4363 & 5.2840 & 0.0000 \\
FTSE & CG & ULRV & 217 & 0.0026 & 0.0038 & 0.0272 & 0.7129 & 6.8438 & 0.0000 \\
FTSE & CG & RB & 217 & 0.0017 & 0.0044 & 0.0264 & -0.1420 & 4.8439 & 0.0000 \\
FTSE & Pharma. & Shire & 217 & 0.0023 & 0.0017 & 0.0471 & 0.0947 & 11.6653 & 0.0000 \\
FTSE & Tobacco & IMB & 217 & 0.0008 & 0.0032 & 0.0288 & -0.0803 & 4.0196 & 0.0081
\end{tabular}




\begin{tabular}{|c|c|c|c|c|c|c|c|c|c|}
\hline FTSE & Retailing & Tesco & 217 & 0.0002 & 0.0009 & 0.0435 & 0.0381 & 4.5561 & 0.0000 \\
\hline FTSE & BM & CRH & 217 & 0.0028 & 0.0024 & 0.0326 & 0.2122 & 3.2697 & 0.3189 \\
\hline FTSE & Aerospace & BAE & 217 & 0.0026 & 0.0000 & 0.0275 & 0.4529 & 4.5040 & 0.0000 \\
\hline FTSE & Aerospace & RR & 217 & 0.0010 & -0.0018 & 0.0461 & -0.4574 & 8.4740 & 0.0000 \\
\hline FTSE & ME & SN & 217 & 0.0020 & 0.0019 & 0.0289 & 0.2156 & 4.1149 & 0.0016 \\
\hline FTSE & Fashion & Burberry & 217 & 0.0023 & 0.0017 & 0.0357 & -0.4120 & 4.7935 & 0.0000 \\
\hline FTSE & Food Prc. & $\mathrm{ABF}$ & 217 & -0.0004 & 0.0000 & 0.0329 & -0.4581 & 4.5095 & 0.0000 \\
\hline FTSE & Retail & NXT & 217 & 0.0003 & 0.0025 & 0.0367 & -0.3337 & 7.7703 & 0.0000 \\
\hline FTSE & Packaging & Mondi & 217 & 0.0035 & 0.0060 & 0.0337 & -0.4810 & 4.4487 & 0.0000 \\
\hline FTSE & Packaging & SKG & 217 & 0.0045 & 0.0062 & 0.0416 & 1.9719 & 17.9847 & 0.0000 \\
\hline FTSE & Chemicals & JMAT & 217 & 0.0009 & 0.0027 & 0.0373 & 1.1228 & 9.2298 & 0.0000 \\
\hline FTSE & Retail & KGF & 217 & -0.0007 & -0.0006 & 0.0315 & -0.6572 & 4.8343 & 0.0000 \\
\hline FTSE & Engineer. & SMIN & 217 & 0.0030 & 0.0024 & 0.0323 & 0.0281 & 3.6466 & 0.1489 \\
\hline FTSE & Chemicals & Croda & 217 & 0.0033 & 0.0066 & 0.0283 & -0.0743 & 4.3497 & 0.0002 \\
\hline SU & Bottling & & 217 & 0.0039 & 0.0031 & 0.0340 & 0.3012 & 4.5994 & 0.0000 \\
\hline SE & Retail & $\mathrm{M} \& \mathrm{~S}$ & 217 & -0.0010 & 0.0020 & 0.0345 & 0.1280 & 4.7831 & 0.0000 \\
\hline FTSE & Housebuild & Barratt & 217 & 0.0026 & 0.0049 & 0.0382 & -0.4446 & 4.3844 & 0.0000 \\
\hline FTSE & Steel & Evraz & 217 & 0.0107 & 0.0051 & 0.0825 & 1.1935 & 6.9470 & 0.0000 \\
\hline IBEX & Retailing & ITX SA & 217 & 0.0020 & 0.0020 & 0.0291 & 0.0931 & 3.0479 & 0.8462 \\
\hline IBEX & Transport. & FER & 217 & 0.0009 & 0.0032 & 0.0282 & -0.3177 & 2.7599 & 0.1242 \\
\hline IBEX & $\mathrm{CE}$ & ACS & 217 & 0.0015 & 0.0019 & 0.0389 & 0.0975 & 3.6442 & 0.1290 \\
\hline IBEX & Pharma. & Grifols SA & 217 & 0.0017 & 0.0022 & 0.0347 & -0.3451 & 3.9456 & 0.0020 \\
\hline IBEX & Steel & MT & 217 & 0.0018 & -0.0044 & 0.0653 & 1.3973 & 9.8551 & 0.0000 \\
\hline IBEX & Engineering & SGRE & 217 & 0.0031 & 0.0067 & 0.0506 & -0.3053 & 3.7331 & 0.0163 \\
\hline IBEX & Meat,Casings & Viscofan SA & 217 & 0.0019 & 0.0020 & 0.0255 & 0.0863 & 3.7346 & 0.0762 \\
\hline IBEX & Steel & Acerinox SA & 217 & 0.0005 & -0.0016 & 0.0452 & 0.5569 & 4.4113 & 0.0000 \\
\hline IBEX & Automotive & CIE & 217 & 0.0063 & 0.0090 & 0.0367 & -0.6088 & 4.3868 & 0.0000 \\
\hline IBEX & Retail & DIA & 217 & -0.0043 & -0.0013 & 0.0453 & 0.0404 & 4.5588 & 0.0000 \\
\hline DAX & Automotive & BMW & 217 & 0.0001 & 0.0005 & 0.0360 & 0.1892 & 4.6716 & 0.0000 \\
\hline DAX & Automotive & Volkswagen & 217 & -0.0003 & -0.0019 & 0.0446 & -0.3804 & 13.6247 & 0.0000 \\
\hline DAX & Apparel & Adidas & 217 & 0.0048 & 0.0053 & 0.0375 & -0.1955 & 5.9938 & 0.0000 \\
\hline DAX & Automotive & Daimler & 217 & -0.0002 & 0.0033 & 0.0352 & -0.0694 & 3.7729 & 0.0616 \\
\hline DAX & Tires & Continental & 217 & 0.0012 & 0.0000 & 0.0343 & 0.2593 & 3.6039 & 0.0570 \\
\hline DAX & FMCG & Henkel & 217 & 0.0014 & 0.0013 & 0.0253 & -0.2314 & 3.4342 & 0.1620 \\
\hline DAX & FMCG & Beiersdorf & 217 & 0.0018 & 0.0007 & 0.0251 & -0.0134 & 4.0716 & 0.0055 \\
\hline DAX & Pharma. & Bayer & 217 & 0.0001 & 0.0009 & 0.0336 & -0.0980 & 3.3512 & 0.4814 \\
\hline DAX & Health care & FRE & 217 & 0.0035 & 0.0051 & 0.0314 & -0.1280 & 4.0419 & 0.0055 \\
\hline DAX & Chemicals & Merck & 217 & 0.0019 & 0.0026 & 0.0291 & -0.1319 & 2.8605 & 0.6687 \\
\hline DAX & Health care & FME & 217 & 0.0030 & 0.0026 & 0.0283 & 0.0960 & 5.7523 & 0.0000 \\
\hline
\end{tabular}




\begin{tabular}{lccccccccc}
\hline DAX & Industrial & Siemens & 217 & 0.0013 & 0.0034 & 0.0303 & -0.0926 & 3.3348 & 0.5159 \\
DAX & Chemicals & BASF & 217 & 0.0005 & 0.0016 & 0.0316 & -0.1937 & 3.4116 & 0.2358 \\
DAX & BM & HEI & 217 & 0.0011 & 0.0013 & 0.0312 & 0.0562 & 2.9161 & 0.9150 \\
DAX & Industrial & Thyssenkrup & & & & & & & \\
& & p & 217 & 0.0009 & 0.0014 & 0.0434 & 0.3535 & 3.6077 & 0.0197 \\
DAX & Industrial gas & Linde & 47 & 0.0069 & 0.0052 & 0.0300 & 0.0770 & 2.9882 & 0.9769 \\
DAX & Chemicals & Covestro & 145 & 0.0085 & 0.0077 & 0.0400 & -0.0187 & 3.7345 & 0.1951 \\
\hline & & & & Currency and Index returns & & & \\
\hline GBP/EUR & & & 217 & -0.0004 & -0.0014 & 0.0121 & -0.0065 & 3.7586 & 0.0741 \\
FTSE100 & & & 217 & 0.0007 & 0.0030 & 0.0187 & -0.2498 & 4.5614 & 0.0000 \\
IBEX35 & & & 217 & 0.0000 & 0.0022 & 0.0260 & -0.2078 & 3.1978 & 0.3838 \\
DAX30 & & & 217 & 0.0015 & 0.0035 & 0.0247 & -0.3335 & 3.6010 & 0.0261 \\
\hline
\end{tabular}

\begin{tabular}{|c|c|c|c|c|c|c|c|c|}
\hline \multicolumn{9}{|c|}{ Panel B: 05/30/2014-06/17/2016 } \\
\hline Index & Company & $\mathrm{N}$ & Mean & Median & SD & $\mathrm{S}$ & $\mathrm{K}$ & p-Value JB \\
\hline FTSE & BAT & 108 & 0.0018 & 0.0039 & 0.0271 & -0.1374 & 3.7867 & 0.2096 \\
\hline FTSE & GSK & 108 & -0.0011 & -0.0017 & 0.0256 & -0.3701 & 3.4827 & 0.1726 \\
\hline FTSE & AZN & 108 & -0.0008 & 0.0001 & 0.0292 & 0.1752 & 4.0692 & 0.0579 \\
\hline FTSE & DEO & 108 & -0.0004 & 0.0001 & 0.0246 & -0.0698 & 3.2584 & 0.8235 \\
\hline FTSE & ULRV & 108 & 0.0016 & 0.0038 & 0.0246 & -0.2632 & 2.8415 & 0.5066 \\
\hline FTSE & $\mathrm{RB}$ & 108 & 0.0031 & 0.0045 & 0.0236 & 0.5568 & 4.5797 & 0.0002 \\
\hline FTSE & Shire & 108 & 0.0028 & 0.0073 & 0.0510 & -0.5964 & 13.8443 & 0.0000 \\
\hline FTSE & IMB & 108 & 0.0031 & 0.0076 & 0.0283 & -0.1737 & 2.8499 & 0.7244 \\
\hline FTSE & Tesco & 108 & -0.0050 & -0.0021 & 0.0504 & 0.0217 & 3.8557 & 0.1917 \\
\hline FTSE & $\mathrm{CRH}$ & 108 & 0.0025 & 0.0062 & 0.0358 & 0.1624 & 3.1615 & 0.7437 \\
\hline FTSE & BAE & 108 & 0.0017 & 0.0004 & 0.0287 & 0.1793 & 3.8336 & 0.1568 \\
\hline FTSE & RR & 108 & -0.0032 & -0.0032 & 0.0502 & -1.0654 & 9.1571 & 0.0000 \\
\hline FTSE & $\mathrm{SN}$ & 108 & 0.0020 & 0.0019 & 0.0329 & 0.3521 & 3.6435 & 0.1291 \\
\hline FTSE & Burberry & 108 & -0.0023 & -0.0014 & 0.0371 & -0.2837 & 5.0337 & 0.0000 \\
\hline FTSE & $\mathrm{ABF}$ & 108 & -0.0001 & 0.0024 & 0.0334 & -0.3921 & 3.1709 & 0.2348 \\
\hline FTSE & NXT & 108 & -0.0016 & 0.0046 & 0.0272 & -1.7662 & 9.5919 & 0.0000 \\
\hline FTSE & Mondi & 108 & 0.0024 & 0.0055 & 0.0379 & -0.5398 & 4.2976 & 0.0016 \\
\hline FTSE & $\mathrm{SKG}$ & 108 & 0.0028 & 0.0075 & 0.0364 & -0.3366 & 3.1957 & 0.3310 \\
\hline FTSE & JMAT & 108 & -0.0012 & 0.0031 & 0.0382 & 0.1220 & 3.5325 & 0.4621 \\
\hline FTSE & KGF & 108 & -0.0009 & -0.0004 & 0.0313 & -0.3737 & 3.7563 & 0.0786 \\
\hline FTSE & SMIN & 108 & 0.0020 & 0.0018 & 0.0358 & -0.1260 & 3.0126 & 0.8666 \\
\hline FTSE & Croda & 108 & 0.0010 & 0.0034 & 0.0304 & -0.2963 & 3.4673 & 0.2777 \\
\hline FTSE & $\mathrm{CCH}$ & 108 & 0.0008 & -0.0035 & 0.0351 & -0.0744 & 3.7878 & 0.2354 \\
\hline FTSE & $M \& S$ & 108 & -0.0015 & -0.0016 & 0.0372 & 0.3075 & 5.4469 & 0.0000 \\
\hline
\end{tabular}




\begin{tabular}{|c|c|c|c|c|c|c|c|c|}
\hline FTSE & Barratt & 108 & 0.0044 & 0.0074 & 0.0375 & -0.1887 & 2.3082 & 0.2473 \\
\hline FTSE & Evraz & 108 & 0.0041 & 0.0001 & 0.0895 & 1.6398 & 8.3381 & 0.0000 \\
\hline IBEX & ITX SA & 108 & 0.0018 & 0.0039 & 0.0271 & -0.1374 & 3.7867 & 0.2096 \\
\hline IBEX & FER & 108 & -0.0011 & -0.0017 & 0.0256 & -0.3701 & 3.4827 & 0.1726 \\
\hline IBEX & ACS & 108 & -0.0005 & -0.0007 & 0.0440 & 0.1900 & 3.2623 & 0.6191 \\
\hline IBEX & Grifols SA & 108 & 0.0004 & 0.0041 & 0.0393 & -0.4463 & 3.6112 & 0.0718 \\
\hline IBEX & MT & 108 & -0.0030 & -0.0131 & 0.0791 & 1.6205 & 9.1784 & 0.0000 \\
\hline IBEX & SGRE & 108 & 0.0088 & 0.0097 & 0.0541 & -0.2302 & 3.2810 & 0.5196 \\
\hline IBEX & Viscofan SA & 108 & 0.0018 & 0.0039 & 0.0274 & 0.1197 & 2.8580 & 0.8401 \\
\hline IBEX & Acerinox SA & 108 & -0.0007 & -0.0017 & 0.0534 & 0.5419 & 3.8984 & 0.0116 \\
\hline IBEX & CIE & 108 & 0.0061 & 0.0096 & 0.0405 & -0.6981 & 3.9476 & 0.0017 \\
\hline IBEX & DIA & 108 & -0.0014 & 0.0009 & 0.0455 & 0.0532 & 3.3055 & 0.7902 \\
\hline DAX & BMW & 108 & -0.0016 & -0.0019 & 0.0425 & 0.1104 & 3.9134 & 0.1371 \\
\hline DAX & Volkswagen & 108 & -0.0020 & -0.0038 & 0.0563 & -0.3218 & 10.6111 & 0.0000 \\
\hline DAX & Adidas & 108 & 0.0046 & 0.0062 & 0.0399 & -0.5790 & 6.6988 & 0.0000 \\
\hline DAX & Daimler & 108 & -0.0010 & 0.0022 & 0.0413 & -0.0964 & 3.2061 & 0.8359 \\
\hline DAX & Continental & 108 & 0.0015 & -0.0031 & 0.0408 & 0.2531 & 2.8841 & 0.5451 \\
\hline DAX & Henkel & 108 & 0.0019 & 0.0007 & 0.0275 & -0.2861 & 3.1319 & 0.4603 \\
\hline DAX & Beiersdorf & 108 & 0.0009 & 0.0003 & 0.0281 & 0.1862 & 3.7576 & 0.2012 \\
\hline DAX & Bayer & 108 & -0.0007 & 0.0005 & 0.0382 & -0.2006 & 2.9501 & 0.6924 \\
\hline DAX & FRE & 108 & 0.0056 & 0.0079 & 0.0337 & -0.2679 & 4.3830 & 0.0071 \\
\hline DAX & Merck & 108 & 0.0036 & 0.0031 & 0.0328 & -0.1285 & 2.5870 & 0.5872 \\
\hline DAX & FME & 108 & 0.0044 & 0.0033 & 0.0319 & 0.2356 & 5.8820 & 0.0000 \\
\hline DAX & Siemens & 108 & 0.0001 & 0.0031 & 0.0328 & -0.1556 & 3.0322 & 0.8023 \\
\hline DAX & BASF & 108 & -0.0012 & 0.0002 & 0.0369 & -0.1129 & 3.0484 & 0.8869 \\
\hline DAX & HEI & 108 & 0.0019 & 0.0030 & 0.0353 & -0.0994 & 2.6666 & 0.7124 \\
\hline DAX & Thyssenkrupp & 108 & -0.0006 & -0.0027 & 0.0475 & 0.5061 & 3.8201 & 0.0220 \\
\hline DAX & Linde & 0 & NA & NA & NA & NA & NA & NA \\
\hline DAX & Covestro & 36 & 0.0127 & 0.0123 & 0.0461 & -0.4420 & 3.6539 & 0.4038 \\
\hline \multicolumn{9}{|c|}{ Currency and Index returns } \\
\hline GBP/EUR & & 108 & 0.0004 & -0.0014 & 0.0122 & 0.0507 & 3.1546 & 0.9260 \\
\hline FTSE100 & & 108 & -0.0009 & 0.0025 & 0.0212 & -0.2836 & 3.5032 & 0.2744 \\
\hline IBEX35 & & 108 & -0.0017 & 0.0013 & 0.0295 & -0.1360 & 2.6210 & 0.6128 \\
\hline DAX30 & & 108 & 0.0003 & 0.0048 & 0.0292 & -0.2817 & 2.9203 & 0.4825 \\
\hline \multicolumn{9}{|c|}{ Panel C: 06/24/2016-07/20/2018 } \\
\hline Index & Company & $\mathrm{N}$ & Mean & Median & $\mathrm{SD}$ & $\bar{S}$ & $\overline{\mathrm{K}}$ & $p$-Value JB \\
\hline FTSE & BAT & 109 & 0.0001 & 0.0037 & 0.0318 & -0.1101 & 5.1651 & 0.0000 \\
\hline FTSE & GSK & 109 & 0.0013 & 0.0027 & 0.0253 & -0.4316 & 5.8776 & 0.0000 \\
\hline FTSE & AZN & 109 & 0.0042 & 0.0036 & 0.0350 & 0.1087 & 5.8989 & 0.0000 \\
\hline FTSE & DEO & 109 & 0.0048 & 0.0062 & 0.0246 & 0.9570 & 6.9802 & 0.0000 \\
\hline FTSE & ULRV & 109 & 0.0037 & 0.0035 & 0.0297 & 1.2208 & 8.2164 & 0.0000 \\
\hline FTSE & $\mathrm{RB}$ & 109 & 0.0002 & 0.0041 & 0.0288 & -0.4714 & 4.5613 & 0.0005 \\
\hline FTSE & Shire & 109 & 0.0018 & -0.0036 & 0.0431 & 1.2098 & 6.6379 & 0.0000 \\
\hline FTSE & IMB & 109 & -0.0015 & 0.0024 & 0.0293 & 0.0172 & 5.1042 & 0.0000 \\
\hline FTSE & Tesco & 109 & 0.0053 & 0.0049 & 0.0348 & 0.5757 & 4.7790 & 0.0000 \\
\hline FTSE & $\mathrm{CRH}$ & 109 & 0.0031 & -0.0004 & 0.0291 & 0.3109 & 3.0904 & 0.4079 \\
\hline FTSE & BAE & 109 & 0.0035 & 0.0000 & 0.0264 & 0.8163 & 5.2827 & 0.0000 \\
\hline FTSE & $\mathrm{RR}$ & 109 & 0.0052 & -0.0008 & 0.0414 & 0.7648 & 5.2605 & 0.0000 \\
\hline FTSE & SN & 109 & 0.0020 & 0.0025 & 0.0245 & -0.1374 & 4.3087 & 0.0172 \\
\hline FTSE & Burberry & 109 & 0.0069 & 0.0069 & 0.0340 & -0.5209 & 4.5953 & 0.0003 \\
\hline FTSE & $\mathrm{ABF}$ & 109 & -0.0008 & -0.0014 & 0.0326 & -0.5295 & 5.9526 & 0.0000 \\
\hline FTSE & NXT & 109 & 0.0022 & 0.0016 & 0.0441 & -0.0561 & 5.9830 & 0.0000 \\
\hline FTSE & Mondi & 109 & 0.0047 & 0.0064 & 0.0291 & -0.2333 & 3.6551 & 0.2302 \\
\hline FTSE & SKG & 109 & 0.0061 & 0.0028 & 0.0463 & 2.9945 & 21.9289 & 0.0000 \\
\hline FTSE & JMAT & 109 & 0.0030 & 0.0013 & 0.0364 & 2.2962 & 15.6217 & 0.0000 \\
\hline FTSE & KGF & 109 & -0.0005 & -0.0010 & 0.0318 & -0.9246 & 5.8443 & 0.0000 \\
\hline FTSE & SMIN & 109 & 0.0039 & 0.0027 & 0.0285 & 0.3863 & 4.5238 & 0.0013 \\
\hline
\end{tabular}




\begin{tabular}{|c|c|c|c|c|c|c|c|c|}
\hline $\begin{array}{l}\text { FTSE } \\
\end{array}$ & Croda & 109 & 0.0055 & 0.0075 & 0.0259 & 0.3761 & 5.4517 & 0.0000 \\
\hline FTSE & $\mathrm{CCH}$ & 109 & 0.0069 & 0.0060 & 0.0327 & 0.8105 & 5.3334 & 0.0000 \\
\hline FTSE & $M \& S$ & 109 & -0.0006 & 0.0031 & 0.0318 & -0.1436 & 3.2810 & 0.6931 \\
\hline FTSE & Barratt & 109 & 0.0008 & 0.0039 & 0.0390 & -0.6622 & 6.0527 & 0.0000 \\
\hline FTSE & Evraz & 109 & 0.0172 & 0.0143 & 0.0749 & 0.5438 & 4.4346 & 0.0006 \\
\hline IBEX & ITX SA & 109 & 0.0004 & 0.0005 & 0.0266 & -0.0380 & 3.0403 & 0.9834 \\
\hline IBEX & FER & 109 & 0.0004 & 0.0029 & 0.0272 & -0.3669 & 2.9669 & 0.2937 \\
\hline IBEX & ACS & 109 & 0.0035 & 0.0027 & 0.0331 & 0.0127 & 3.8713 & 0.1781 \\
\hline IBEX & Grifols SA & 109 & 0.0031 & 0.0002 & 0.0295 & 0.0300 & 3.6206 & 0.4136 \\
\hline IBEX & ArcelorMitta & 109 & 0.0066 & 0.0010 & 0.0476 & 0.3761 & 3.1430 & 0.2641 \\
\hline IBEX & SGRE & 109 & -0.0026 & 0.0038 & 0.0465 & -0.5604 & 4.2772 & 0.0014 \\
\hline IBEX & Viscofan SA & 109 & 0.0020 & 0.0006 & 0.0237 & 0.0372 & 5.0784 & 0.0001 \\
\hline IBEX & Acerinox SA & 109 & 0.0017 & -0.0008 & 0.0353 & 0.6075 & 3.6273 & 0.0143 \\
\hline IBEX & CIE & 109 & 0.0065 & 0.0073 & 0.0326 & -0.4005 & 4.7584 & 0.0002 \\
\hline IBEX & DIA & 109 & -0.0072 & -0.0019 & 0.0451 & 0.0238 & 5.8690 & 0.0000 \\
\hline DAX & BMW & 109 & 0.0017 & 0.0007 & 0.0282 & 0.6317 & 4.7639 & 0.0000 \\
\hline DAX & Volkswagen & 109 & 0.0013 & 0.0012 & 0.0287 & 0.0506 & 2.5630 & 0.6332 \\
\hline DAX & Adidas & 109 & 0.0050 & 0.0025 & 0.0351 & 0.3702 & 4.5469 & 0.0013 \\
\hline DAX & Daimler & 109 & 0.0006 & 0.0042 & 0.0280 & 0.1305 & 3.7981 & 0.2017 \\
\hline DAX & Continental & 109 & 0.0010 & 0.0032 & 0.0267 & 0.1804 & 4.2726 & 0.0188 \\
\hline DAX & Henkel & 109 & 0.0008 & 0.0023 & 0.0231 & -0.1641 & 3.7733 & 0.2014 \\
\hline DAX & Beiersdorf & 109 & 0.0026 & 0.0019 & 0.0218 & -0.3603 & 4.1690 & 0.0138 \\
\hline DAX & Bayer & 109 & 0.0010 & 0.0009 & 0.0286 & 0.2245 & 3.5049 & 0.3546 \\
\hline DAX & FRE & 109 & 0.0015 & 0.0038 & 0.0289 & 0.0150 & 3.3005 & 0.8129 \\
\hline DAX & Merck & 109 & 0.0002 & 0.0026 & 0.0249 & -0.2804 & 2.9068 & 0.4801 \\
\hline DAX & FME & 109 & 0.0017 & 0.0014 & 0.0243 & -0.3397 & 3.7580 & 0.0951 \\
\hline DAX & Siemens & 109 & 0.0025 & 0.0034 & 0.0276 & 0.0671 & 3.5987 & 0.4254 \\
\hline DAX & BASF & 109 & 0.0022 & 0.0038 & 0.0255 & -0.1828 & 2.9206 & 0.7278 \\
\hline DAX & HEI & 109 & 0.0002 & 0.0003 & 0.0267 & 0.3350 & 2.9403 & 0.3579 \\
\hline DAX & Thyssenkrup & 109 & 0.0023 & 0.0040 & 0.0390 & 0.1212 & 2.8508 & 0.8320 \\
\hline DAX & Linde & 47 & 0.0069 & 0.0052 & 0.0300 & 0.0770 & 2.9882 & 0.9769 \\
\hline DAX & Covestro & 109 & 0.0072 & 0.0059 & 0.0379 & 0.1758 & 3.7427 & 0.2158 \\
\hline \multicolumn{9}{|c|}{ Currency and Index returns } \\
\hline GBP/EUR & & 109 & -0.0011 & -0.0016 & 0.0120 & -0.0699 & 4.3685 & 0.0136 \\
\hline FTSE100 & & 109 & 0.0024 & 0.0039 & 0.0159 & 0.0844 & 6.2825 & 0.0000 \\
\hline IBEX35 & & 109 & 0.0016 & 0.0042 & 0.0220 & -0.1801 & 3.9923 & 0.0796 \\
\hline DAX30 & & 109 & 0.0026 & 0.0033 & 0.0194 & -0.2068 & 4.0314 & 0.0606 \\
\hline \multicolumn{9}{|c|}{$\begin{array}{l}\text { GSK is in pharmaceuticals, biotechnology, and Consumer Goods. AZN is in pharmaceutical and biotechnology. } \\
\text { BAE is in Aerospace, Arms Industry, and information security. Evraz is in steel and mining. ABF is in food } \\
\text { processing and retailing. Mondi is in packaging and paper. Grifols is in Pharmaceutical and Chemicals. Adidas is } \\
\text { in apparel and accessories. Bayer is in pharmaceuticals, life sciences, and chemicals. Merck is in chemicals and } \\
\text { pharmaceuticals. Siemens is a conglomerate and Industry, Energy, Healthcare and Infrastructure \& Cities } \\
\text { represent the main activities of the company. Linde is a chemical company and the world's largest industrial } \\
\text { gas producer by market share as well as revenue. ThyssenKrupp is a conglomerate, with products from and } \\
\text { industrial services to high-speed trains, elevators, and shipbuilding. CE stands for civil engineering. CG stands } \\
\text { for Consumer Goods. BM stands for Building Materials. ME stands for Medical Equipment. FMCG stands for } \\
\text { Fast-Moving Consumer Goods. }\end{array}$} \\
\hline
\end{tabular}


Table 3.

Firm-level $F X$ exposure response coefficients before and after the Brexit referendum.

\begin{tabular}{|c|c|c|c|c|}
\hline Panel A & & & & \\
\hline \multirow{2}{*}{ Company return } & Eq. (1) & Eq. (1a) & Eq. (1b) & Eq. (1') \\
\hline & Coefficient & Coefficient & Coefficient & Coefficient \\
\hline $\begin{array}{l}\text { Index Exposure } \\
\qquad\left(\beta_{\text {Market }}\right)\end{array}$ & $\begin{array}{l}0.9280 * * * \\
{[0.0154]}\end{array}$ & - & $\begin{array}{l}0.9254 * * * \\
{[0.0153]}\end{array}$ & $\begin{array}{c}0.9283 * * * \\
{[0.0154]}\end{array}$ \\
\hline $\begin{array}{l}\text { Currency Exposure } \\
\quad\left(\beta_{\text {currency }}\right)\end{array}$ & $\begin{array}{c}0.0216 \\
{[0.0285]}\end{array}$ & - & $\begin{array}{c}0.0246 \\
{[0.0284]}\end{array}$ & - \\
\hline$\beta_{\text {currency }}^{-}$ & - & - & - & 0.0292 \\
\hline$\beta_{\text {currency }}^{+}$ & - & - & - & $\begin{array}{l}-0.0156 \\
{[0.0870]}\end{array}$ \\
\hline $\begin{array}{l}\text { Treatment effect } \\
\qquad\left(\gamma_{2}\right)\end{array}$ & $\begin{array}{l}-0.0006 \\
{[0.0006]}\end{array}$ & $\begin{array}{l}-0.0005 \\
{[0.0011]}\end{array}$ & - & $\begin{array}{l}-0.0006 \\
{[0.0009]}\end{array}$ \\
\hline $\operatorname{Brexit}\left(\gamma_{1}\right)$ & $\begin{array}{c}-0.0024 * * * \\
{[0.0008]}\end{array}$ & $\begin{array}{c}0.0007 \\
{[0.0010]}\end{array}$ & - & $\begin{array}{c}-0.0024 * * * \\
{[0.0008]}\end{array}$ \\
\hline $\begin{array}{l}\text { Interaction } \\
\operatorname{Term}\left(\gamma_{3}\right)\end{array}$ & $\begin{array}{l}0.0022 * \\
{[0.0012]}\end{array}$ & $\begin{array}{c}0.0018 \\
{[0.0014]}\end{array}$ & - & $\begin{array}{l}0.0022 \\
{[.0012]}\end{array}$ \\
\hline cons & $\begin{array}{c}0.0021 * * * \\
{[0.0006]}\end{array}$ & $\begin{array}{l}0.0014 * \\
{[0.0008]} \\
\end{array}$ & $\begin{array}{c}0.0011 * * * \\
{[0.0003]}\end{array}$ & $\begin{array}{l}0.0022 * * * \\
{[0.0007]}\end{array}$ \\
\hline R-squared & $30.85 \%$ & $0.06 \%$ & $30.79 \%$ & $30.85 \%$ \\
\hline \multicolumn{5}{|l|}{ Panel B } \\
\hline & Brexit & FTSEFIRM & & Return \\
\hline $\begin{array}{l}\text { Firms that do not belong to } \\
\text { FTSE100 before 06/24/2016 }\end{array}$ & 0 & 0 & & 0.0014 \\
\hline $\begin{array}{l}\text { Firms that do not belong to } \\
\text { FTSE100 after 06/24/2016 }\end{array}$ & 1 & 0 & & 0.0020 \\
\hline $\begin{array}{c}\text { Firms that belong to FTSE100 } \\
\text { before } 06 / 24 / 2016\end{array}$ & 0 & 1 & & 0.0009 \\
\hline \multirow[t]{4}{*}{$\begin{array}{c}\text { Firms that belong to FTSE100 } \\
\text { after } 06 / 24 / 2016\end{array}$} & 1 & 1 & & 0.0033 \\
\hline & $\begin{array}{l}\text { in the } \\
\text { control group }\end{array}$ & $\begin{array}{l}\text { in the } \\
\text { treatment } \\
\text { group }\end{array}$ & & $\begin{array}{l}\text { Diff in Diff } \\
\text { estimator }\end{array}$ \\
\hline & \multicolumn{4}{|c|}{ Average change in Returns before and after Brexit referendum } \\
\hline & -0.0005 & 0.0013 & & 0.0018 \\
\hline
\end{tabular}


Notes: Standard errors of estimates are reported in [brackets]. Standard errors are corrected for autocorrelation and heteroscedasticity with the Newey-West procedure. *significance at the $10 \%$ level, ** significance at the $5 \%$ level, *** significance at the $1 \%$ level. Brexit is a dummy variable that takes the value of one for the weeks after the Brexit referendum 06/24/2016 and zero otherwise. FTSEfirm is a dummy variable that takes the value of one for the firms that belong to FTSE100 and zero otherwise. The interaction term captures the firms that belong to FTSE100 during the period after the referendum.

Table 4.

Bilateral $F X$ exposures of stock and market returns.

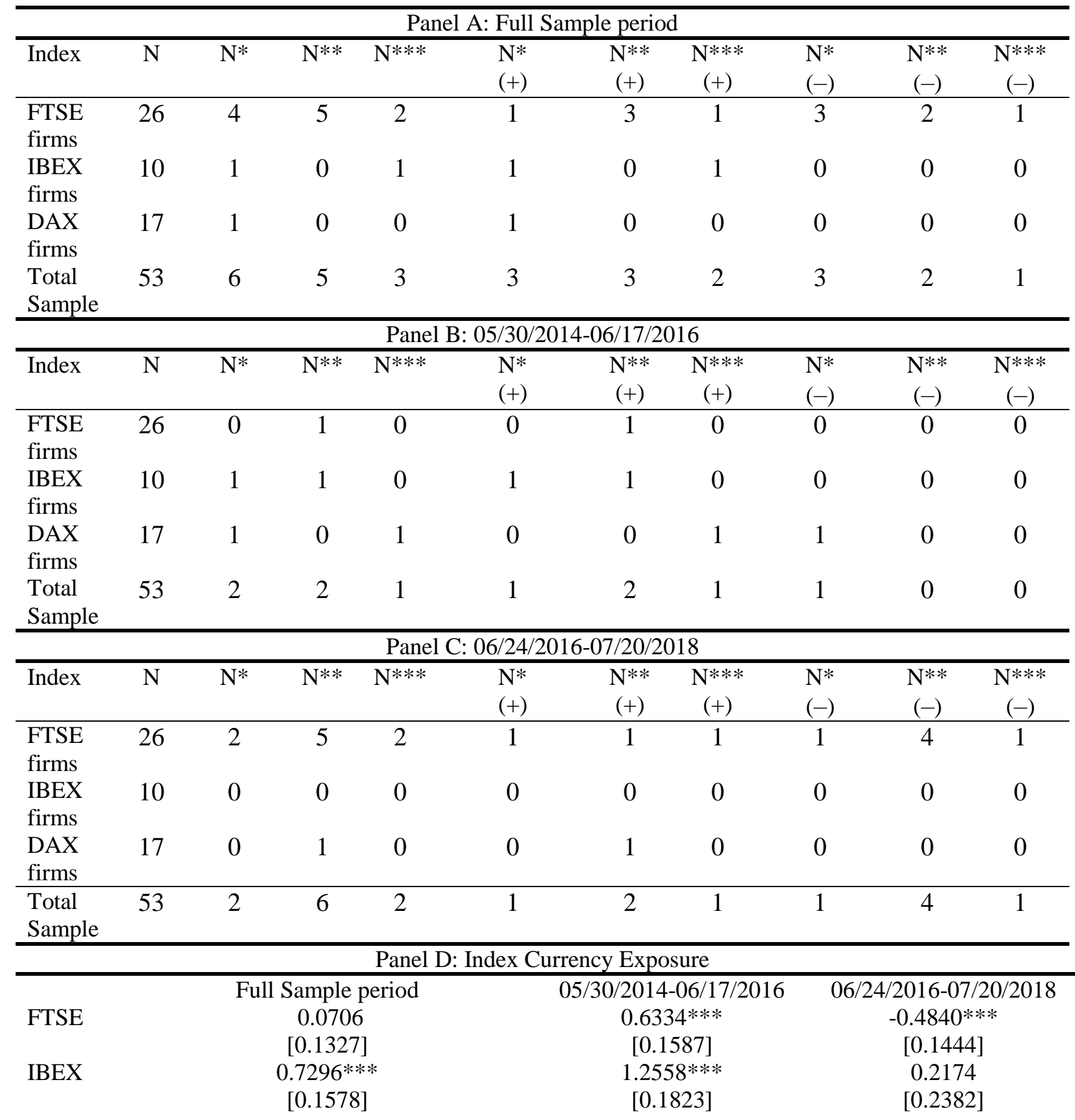




\begin{tabular}{cccc} 
DAX & $0.8416 * * *$ & $1.4124 * * *$ & $0.2797 *$ \\
& {$[0.1373]$} & {$[0.1905]$} & {$[0.1499]$} \\
\hline
\end{tabular}

Notes: In this Table, we test the hypotheses H2 "The foreign exchange exposure at firm and market levels increases after the referendum" and H3 "The foreign exchange exposure at the firm and market levels after the referendum is most severe for British firms." Standard errors of estimates are reported in [brackets]. Standard errors are corrected for autocorrelation and heteroscedasticity with the Newey-West procedure. * significance at the $10 \%$ level, $* *$ significance at the $5 \%$ level, $* * *$ significance at the $1 \%$ level. For space reasons, this table offers a summary of the firm exchange rate exposures (Panels A-C) from estimating Eq. (2). Panel D offers the index exchange rate exposures from estimating Eq. (2'). Separated into pre-referendum and post-referendum and full sample periods, we present the number of firms, $\mathrm{N}$, the number of firms that are significantly exposed $\mathrm{N}^{*}$ (at $10 \%), \mathrm{N}^{* *}($ at $5 \%), \mathrm{N}^{* * *}($ at $1 \%)$, the number of firms that are significantly positive exposed $\mathrm{N}^{*}(+)($ at $10 \%)$,

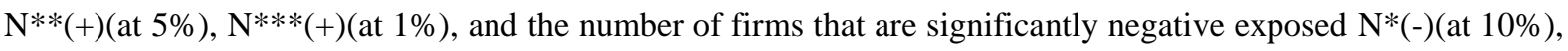
$\mathrm{N}^{* *}(-)($ at $5 \%), \mathrm{N}^{* * *}(-)($ at $1 \%)$. For space reasons, we do not report the R-squares for each regression. The Rsquares for FTSE firms and the full sample period range from $9.38 \%$ to $49.20 \%$ with an average value of $29.24 \%$. The R-squares for IBEX firms and the full sample period range from $22.35 \%$ to $54.17 \%$ with an average value of $34.19 \%$. The R-squares for DAX firms and the full sample period range from $17.83 \%$ to $77.67 \%$ with an average value of 50.07\%. The R-squares for FTSE firms and the pre-referendum period range from $6.78 \%$ to $58.15 \%$ with an average value of $34.76 \%$. The R-squares for IBEX firms and the pre-referendum period range from $23.87 \%$ to $67.82 \%$ with an average value of $42.35 \%$. The R-squares for DAX firms and the pre-referendum period range from $31.01 \%$ to $80.78 \%$ with an average value of $58.74 \%$. Finally, the R-squares for FTSE firms and the postreferendum period range from $6.42 \%$ to $50.86 \%$ with an average value of $25.65 \%$. The R-squares for IBEX firms and the post-referendum period range from $8.97 \%$ to $40.67 \%$ with an average value of $24.86 \%$. The R-squares for DAX firms and the post-referendum period range from $12.92 \%$ to $72.14 \%$ with an average value of $42.33 \%$. The full results are available upon request. 


\section{Table 5.}

Bilateral $F X$ exposures of stock and market returns under four hypotheses: (H4a) The referendum negatively affects the firm- and market- level returns. (H4b) The referendum increases in absolute value the index exposure at the firm level. (H4c) The Brexit vote increases in absolute value the exchange rate exposure at both firm and market levels.

(H4d) The referendum increases in absolute value both the index and currency exposure, at the firm level. NA stands for Not Applicable.

\begin{tabular}{|c|c|c|c|c|c|c|c|c|c|c|c|c|c|}
\hline $\begin{array}{l}\text { Model } \\
\text { (1) }\end{array}$ & $\mathrm{N}$ & $\begin{array}{c}\mathrm{N} *(+) \\
\text { Brexit } \\
\text { term }\end{array}$ & $\begin{array}{c}\mathrm{N} * *(+) \\
\text { Brexit term }\end{array}$ & $\begin{array}{c}\mathrm{N} * * *(+) \\
\text { Brexit term }\end{array}$ & $\begin{array}{c}\mathrm{N}^{*}(-) \\
\text { Brexit term }\end{array}$ & $\begin{array}{c}\mathrm{N}^{* *}(-) \\
\text { Brexit term }\end{array}$ & $\begin{array}{c}\mathrm{N} * * *(-) \\
\text { Brexit term }\end{array}$ & $\begin{array}{c}\mathrm{N}^{*}(+) \\
\text { currency } \\
\text { exposure }\end{array}$ & $\begin{array}{l}\mathrm{N} * *(+) \\
\text { currency } \\
\text { exposure }\end{array}$ & $\begin{array}{l}\mathrm{N} * * *(+) \\
\text { currency } \\
\text { exposure }\end{array}$ & $\begin{array}{c}\mathrm{N}^{*}(-) \\
\text { currency } \\
\text { exposure }\end{array}$ & $\begin{array}{l}\mathrm{N} * *(-) \\
\text { currency } \\
\text { exposure }\end{array}$ & $\begin{array}{l}\mathrm{N} * * *(-) \\
\text { currency } \\
\text { exposure }\end{array}$ \\
\hline $\begin{array}{l}\text { FTSE } \\
\text { firms }\end{array}$ & 26 & 0 & 0 & 0 & 0 & 3 & 0 & 2 & 1 & 1 & 2 & 2 & 1 \\
\hline $\begin{array}{l}\text { IBEX } \\
\text { firms }\end{array}$ & 10 & 0 & 0 & 0 & 1 & 2 & 0 & 1 & 1 & 0 & 0 & 0 & 0 \\
\hline $\begin{array}{l}\text { DAX } \\
\text { firms }\end{array}$ & 17 & 0 & 0 & 0 & 1 & 1 & 0 & 0 & 0 & 0 & 0 & 0 & 0 \\
\hline $\begin{array}{l}\text { Total } \\
\text { Sample }\end{array}$ & 53 & 0 & 0 & 0 & 2 & 6 & 0 & 3 & 2 & 1 & 2 & 2 & 1 \\
\hline $\begin{array}{l}\text { Model } \\
\text { (2) }\end{array}$ & $\mathrm{N}$ & $\begin{array}{c}\mathrm{N}^{*}(+) \\
\text { Brexit } \\
\text { term }\end{array}$ & $\begin{array}{c}\mathrm{N} * *(+) \\
\text { Brexit term }\end{array}$ & $\begin{array}{c}\text { N***(+) } \\
\text { Brexit term }\end{array}$ & $\begin{array}{c}\mathrm{N}^{*}(-) \\
\text { Brexit term }\end{array}$ & $\begin{array}{c}\mathrm{N}^{* *}(-) \\
\text { Brexit term }\end{array}$ & $\begin{array}{c}\mathrm{N} * * *(-) \\
\text { Brexit term }\end{array}$ & $\begin{array}{c}\mathrm{N}^{*}(+) \\
\text { currency } \\
\text { exposure }\end{array}$ & $\begin{array}{l}\mathrm{N} * *(+) \\
\text { currency } \\
\text { exposure }\end{array}$ & $\begin{array}{l}\mathrm{N} * * *(+) \\
\text { currency } \\
\text { exposure }\end{array}$ & $\begin{array}{c}\mathrm{N}^{*}(-) \\
\text { currency } \\
\text { exposure } \\
\end{array}$ & $\begin{array}{c}\mathrm{N} * *(-) \\
\text { currency } \\
\text { exposure } \\
\end{array}$ & $\begin{array}{l}\mathrm{N} * * *(-) \\
\text { currency } \\
\text { exposure }\end{array}$ \\
\hline $\begin{array}{l}\text { FTSE } \\
\text { firms }\end{array}$ & 26 & 1 & 1 & $\overline{0}$ & $\overline{0}$ & $\overline{0}$ & 0 & 0 & 1 & 1 & 0 & 1 & 2 \\
\hline $\begin{array}{l}\text { IBEX } \\
\text { firms }\end{array}$ & 10 & 0 & 0 & 0 & 1 & 1 & 0 & 0 & 2 & 0 & 0 & 0 & 0 \\
\hline $\begin{array}{l}\text { DAX } \\
\text { firms }\end{array}$ & 17 & 0 & 0 & 1 & 0 & 1 & 0 & 1 & 0 & 0 & 1 & 0 & 0 \\
\hline $\begin{array}{l}\text { Total } \\
\text { Sample } \\
\end{array}$ & 53 & 1 & 1 & 1 & 1 & 2 & 0 & 1 & 3 & 1 & 1 & 1 & 2 \\
\hline $\begin{array}{l}\text { Model } \\
\text { (3) }\end{array}$ & $\mathrm{N}$ & $\begin{array}{c}\mathrm{N}^{*}(+) \\
\text { Brexit } \\
\text { term }\end{array}$ & $\begin{array}{c}\mathrm{N} * *(+) \\
\text { Brexit term }\end{array}$ & $\begin{array}{c}\mathrm{N} * * *(+) \\
\text { Brexit term }\end{array}$ & $\begin{array}{c}\mathrm{N}^{*}(-) \\
\text { Brexit term }\end{array}$ & $\begin{array}{c}\mathrm{N}^{* *}(-) \\
\text { Brexit term }\end{array}$ & $\begin{array}{c}\mathrm{N} * * *(-) \\
\text { Brexit term }\end{array}$ & $\begin{array}{l}\mathrm{N} *(+) \\
\text { currency } \\
\text { exposure }\end{array}$ & $\begin{array}{c}\mathrm{N}^{* *}(+) \\
\text { currency } \\
\text { exposure }\end{array}$ & $\begin{array}{l}\mathrm{N} * * *(+) \\
\text { currency } \\
\text { exposure }\end{array}$ & $\begin{array}{c}\mathrm{N}^{*}(-) \\
\text { currency } \\
\text { exposure } \\
\end{array}$ & $\begin{array}{c}\mathrm{N} * *(-) \\
\text { currency } \\
\text { exposure } \\
\end{array}$ & $\begin{array}{l}\mathrm{N}^{* * *}(-) \\
\text { currency } \\
\text { exposure }\end{array}$ \\
\hline FTSE & 26 & 1 & 1 & 0 & 2 & 0 & 0 & 1 & 1 & 0 & 1 & 0 & 0 \\
\hline
\end{tabular}




\begin{tabular}{|c|c|c|c|c|c|c|c|c|c|c|c|c|c|}
\hline $\begin{array}{l}\text { IBEX } \\
\text { firms }\end{array}$ & 10 & 0 & 0 & 0 & 0 & 0 & 0 & 1 & 0 & 0 & 0 & 0 & 0 \\
\hline $\begin{array}{l}\text { DAX } \\
\text { firms }\end{array}$ & 17 & 0 & 1 & 0 & 0 & 0 & 0 & 0 & 1 & 0 & 0 & 0 & 0 \\
\hline Total & 53 & 1 & 2 & 0 & 2 & 0 & 0 & 2 & 2 & 0 & 1 & 0 & 0 \\
\hline \multicolumn{14}{|l|}{ Sample } \\
\hline $\begin{array}{l}\text { Model } \\
\text { (4) }\end{array}$ & $\bar{N}$ & $\begin{array}{c}\mathrm{N}^{*}(+) \\
\text { Brexit term }\end{array}$ & $\begin{array}{c}\mathrm{N}^{* *}(+) \\
\text { Brexit term }\end{array}$ & $\begin{array}{c}\mathrm{N}^{* * *}(+) \\
\text { Brexit term }\end{array}$ & $\begin{array}{c}\mathrm{N}^{*}(-) \\
\text { Brexit term }\end{array}$ & $\begin{array}{c}\mathrm{N} * *(-) \\
\text { Brexit term }\end{array}$ & $\begin{array}{c}\mathrm{N}^{* * *}(-) \\
\text { Brexit term }\end{array}$ & $\begin{array}{c}\mathrm{N}^{*}(+) \\
\text { currency } \\
\text { exposure }\end{array}$ & $\begin{array}{l}\mathrm{N}^{* *}(+) \\
\text { currency } \\
\text { exposure }\end{array}$ & $\begin{array}{l}\mathrm{N}^{* * * *(+)} \\
\text { currency } \\
\text { exposure }\end{array}$ & $\begin{array}{c}\mathrm{N}^{*}(-) \\
\text { currency } \\
\text { exposure }\end{array}$ & $\begin{array}{l}\mathrm{N}^{* *}(-) \\
\text { currency } \\
\text { exposure }\end{array}$ & $\begin{array}{l}\mathrm{N}^{* * *}(-) \\
\text { currency } \\
\text { exposure }\end{array}$ \\
\hline $\begin{array}{l}\text { FTSE } \\
\text { firms }\end{array}$ & 26 & 0 & 1 & 0 & 0 & 0 & 0 & 0 & 1 & 0 & 1 & 0 & 0 \\
\hline $\begin{array}{l}\text { IBEX } \\
\text { firms }\end{array}$ & 10 & 0 & 0 & 0 & 2 & 1 & 1 & 1 & 0 & 0 & 0 & 0 & 0 \\
\hline $\begin{array}{l}\text { DAX } \\
\text { firms }\end{array}$ & 17 & 0 & 1 & 0 & 1 & 1 & 0 & 0 & 1 & 0 & 0 & 1 & 0 \\
\hline $\begin{array}{l}\text { Total } \\
\text { Sample }\end{array}$ & 53 & 0 & 2 & 0 & 3 & 2 & 1 & 1 & 2 & 0 & 1 & 1 & 0 \\
\hline $\begin{array}{l}\text { Model } \\
\text { (4) }\end{array}$ & $\mathrm{N}$ & $\begin{array}{c}\mathrm{N}^{*}(+) \\
\text { currency } \\
\text { Brexit } \\
\text { term }\end{array}$ & $\begin{array}{c}\mathrm{N}^{* *}(+) \\
\text { currency } \\
\text { Brexit term }\end{array}$ & $\begin{array}{c}\mathrm{N} * * *(+) \\
\text { currency } \\
\text { Brexit term }\end{array}$ & $\begin{array}{c}\mathrm{N}^{*}(-) \\
\text { currency } \\
\text { Brexit term }\end{array}$ & $\begin{array}{c}\mathrm{N}^{* *}(-) \\
\text { currency } \\
\text { Brexit term }\end{array}$ & $\begin{array}{c}\mathrm{N}^{* *}(-) \\
\text { currency } \\
\text { Brexit term }\end{array}$ & & & & & & \\
\hline $\begin{array}{l}\text { FTSE } \\
\text { firms }\end{array}$ & 26 & 0 & 1 & 0 & 2 & 0 & 0 & & & & & & \\
\hline $\begin{array}{l}\text { IBEX } \\
\text { firms }\end{array}$ & 10 & 0 & 0 & 0 & 0 & 0 & 0 & & & & & & \\
\hline $\begin{array}{l}\text { DAX } \\
\text { firms }\end{array}$ & 17 & 0 & 0 & 0 & 1 & 0 & 0 & & & & & & \\
\hline Total & 53 & 0 & 1 & 0 & 3 & 0 & 0 & & & & & & \\
\hline \multicolumn{14}{|l|}{ Sample } \\
\hline Index & & $\begin{array}{l}\text { Brexit term } \\
\text { (1) }\end{array}$ & $\begin{array}{l}\text { Cur } \\
\text { Exp } \\
\end{array}$ & & $\begin{array}{l}\text { Brexit term } \\
\text { (2) }\end{array}$ & & $\begin{array}{c}\text { Currency } \\
\text { Exposure } \\
\text { (2) }\end{array}$ & $\begin{array}{c}\text { Brexit term } \\
\text { (3) }\end{array}$ & & $\begin{array}{l}\text { Currency } \\
\text { Exposure } \\
\text { (3) }\end{array}$ & Brex & term & $\begin{array}{c}\text { Currency } \\
\text { Exposure } \\
(4)\end{array}$ \\
\hline
\end{tabular}




\begin{tabular}{|c|c|c|c|c|c|c|c|c|}
\hline FTSE & $\begin{array}{c}0.0030 \\
{[0.0025]}\end{array}$ & $\begin{array}{c}0.0750 \\
{[0.1327]}\end{array}$ & NA & NA & $\begin{array}{c}-1.0385 * * * \\
{[0.2298]}\end{array}$ & $\begin{array}{c}0.5502 * * * \\
{[0.1646]}\end{array}$ & NA & NA \\
\hline IBEX & $\begin{array}{c}0.0052 \\
{[0.0033]}\end{array}$ & $\begin{array}{c}0.7372 * * * \\
{[0.1576]}\end{array}$ & $\mathrm{NA}$ & $\mathrm{NA}$ & $\begin{array}{c}-1.2425 * * * \\
{[0.2764]}\end{array}$ & $\begin{array}{c}1.3034 * * * \\
{[0.1746]}\end{array}$ & NA & NA \\
\hline DAX & $\begin{array}{c}0.0032 \\
{[0.0031]}\end{array}$ & $\begin{array}{c}0.8463 * * * \\
{[0.1374]}\end{array}$ & NA & NA & $\begin{array}{c}-1.0647 * * * \\
{[0.2514]}\end{array}$ & $\begin{array}{c}1.3333 * * * * \\
{[0.1891]}\end{array}$ & NA & NA \\
\hline
\end{tabular}

Notes: Standard errors of estimates are reported in [brackets]. Standard errors are corrected for autocorrelation and heteroscedasticity with the Newey-West procedure. * significance at the $10 \%$ level, ** significance at the $5 \%$ level, $* * *$ significance at the $1 \%$ level. Brexit is a dummy variable that takes the value of one for the weeks after the Brexit referendum 06/24/2016 and zero otherwise. We present the number of firms $\mathrm{N}$, the number of firms that are significantly exposed $\mathrm{N}^{*}($ at $10 \%), \mathrm{N}^{* *}($ at $5 \%), \mathrm{N}^{* * *}($ at $1 \%)$, and the number of firms that are significantly positive exposed $\mathrm{N}^{*}(+)($ at $10 \%), \mathrm{N}^{* *}(+)($ at $5 \%), \mathrm{N}^{* * *}(+)($ at $1 \%)$, and the number of firms that are significantly negative exposed $\mathrm{N}^{*}(-)($ at $10 \%), \mathrm{N}^{* *}(-)($ at $5 \%), \mathrm{N}^{* * *(-)}($ at $1 \%)$. The full results are available upon request. For space reasons, we do not report the $\mathrm{R}$-squares in each regression. The R-squares for FTSE firms under Model 1 range from $9.45 \%$ to $49.26 \%$ with an average value of 29.54\%. The R-squares for IBEX firms, under Model 1 range from $22.43 \%$ to $54.17 \%$ with an average value of 34.69\%. The R-squares for DAX firms under Model 1 range from $18.51 \%$ to $77.68 \%$ with an average value of $50.34 \%$. The R-squares for FTSE firms under Model 2 range from 10.47\% to $49.47 \%$ with an average value of $29.59 \%$. The R-squares for IBEX firms, under Model 2 range from $22.80 \%$ to $54.50 \%$ with an average value of $34.75 \%$. The R-squares for DAX firms under Model 2 range from $17.94 \%$ to $77.69 \%$ with an average value of $50.35 \%$. The R-squares for FTSE firms under Model 3 range from $9.42 \%$ to $49.36 \%$ with an average value of $29.65 \%$. The R-squares for IBEX firms, under Model 3 range from $22.50 \%$ to $54.22 \%$ with an average value of $34.35 \%$. The R-squares for DAX firms under Model 3 range from $18.14 \%$ to $77.70 \%$ with an average value of 50.20\%. The R-squares for FTSE firms under Model 4 range from $10.48 \%$ to $49.60 \%$ with an average value of $29.98 \%$. The R-squares for IBEX firms, under Model 4 range from $22.84 \%$ to $54.66 \%$ with an average value of $35.00 \%$. The R-squares for DAX firms under Model 4 range from $18.61 \%$ to $77.74 \%$ with an average value of $50.52 \%$. 
Table 6.

Bilateral $F X$ exposures of stock and market returns: asymmetry to the direction of $F X$ shocks.

\begin{tabular}{|c|c|c|c|c|c|c|c|c|c|c|c|c|c|c|c|c|}
\hline \multicolumn{17}{|c|}{ Panel A: Full Sample period } \\
\hline Index & $\mathrm{N}$ & $\begin{array}{l}\mathrm{N} \\
*\end{array}$ & $\mathrm{~N}^{* *}$ & $\begin{array}{c}\mathrm{N} * * \\
*\end{array}$ & $\begin{array}{c}\mathrm{N}^{*} \\
(+) \\
\text { due to } \\
\text { deprec } \\
\text { iation } \\
\text { of } \\
\text { GBP/ } \\
\text { EUR }\end{array}$ & $\begin{array}{c}\mathrm{N}^{* *} \\
(+) \\
\text { due to } \\
\text { depreciat } \\
\text { ion } \\
\text { of } \\
\text { GBP/EU } \\
\text { R }\end{array}$ & $\begin{array}{c}\text { N*** } \\
(+) \\
\text { due to } \\
\text { depreciat } \\
\text { ion } \\
\text { of } \\
\text { GBP/EU } \\
\text { R }\end{array}$ & $\begin{array}{c}\mathrm{N}^{*} \\
(-) \\
\text { due to } \\
\text { depreciat } \\
\text { ion of } \\
\text { GBP/EU } \\
\text { R }\end{array}$ & $\begin{array}{c}\mathrm{N}^{* *} \\
(-) \\
\text { due to } \\
\text { depreciat } \\
\text { ion of } \\
\text { GBP/EU } \\
\mathrm{R}\end{array}$ & $\begin{array}{c}\mathrm{N} * * * \\
(-) \\
\text { due to } \\
\text { depreciat } \\
\text { ion of } \\
\text { GBP/EU } \\
\text { R }\end{array}$ & $\begin{array}{c}\mathrm{N}^{*}(+) \\
\text { due to } \\
\text { appreci } \\
\text { ation } \\
\text { of } \\
\text { GBP/E } \\
\text { UR }\end{array}$ & $\begin{array}{c}\mathrm{N}^{* *}(+) \\
\text { due to } \\
\text { appreci } \\
\text { ation of } \\
\text { GBP/E } \\
\text { UR }\end{array}$ & $\begin{array}{c}\text { N***(+ } \\
) \\
\text { due to } \\
\text { appreci } \\
\text { ation of } \\
\text { GBP/E } \\
\text { UR }\end{array}$ & $\begin{array}{l}\mathrm{N}^{*}(-) \\
\text { due to } \\
\text { appreci } \\
\text { ation } \\
\text { of } \\
\text { GBP/E } \\
\text { UR }\end{array}$ & $\begin{array}{c}\mathrm{N}^{* *} \\
(-) \\
\text { due to } \\
\text { appreci } \\
\text { ation } \\
\text { of } \\
\text { GBP/E } \\
\text { UR }\end{array}$ & $\begin{array}{c}\mathrm{N}^{* * *} \\
(-) \\
\text { due to } \\
\text { appreci } \\
\text { ation } \\
\text { of } \\
\text { GBP/E } \\
\text { UR }\end{array}$ \\
\hline $\begin{array}{l}\text { FTSE } \\
\text { firms }\end{array}$ & 26 & 4 & 3 & 1 & 0 & 1 & 0 & 1 & 1 & 0 & 1 & 1 & 0 & 2 & 0 & 1 \\
\hline $\begin{array}{l}\text { IBEX } \\
\text { firms }\end{array}$ & 10 & 0 & 0 & 2 & 0 & 0 & 1 & 0 & 0 & 0 & 0 & 0 & 1 & 0 & 0 & 0 \\
\hline $\begin{array}{l}\text { DAX } \\
\text { firms }\end{array}$ & 17 & 1 & 3 & 1 & 1 & 0 & 0 & 0 & 1 & 0 & 0 & 1 & 1 & 0 & 1 & 0 \\
\hline $\begin{array}{l}\text { Total } \\
\text { Sample }\end{array}$ & 53 & 5 & 6 & 4 & 1 & 1 & 1 & 1 & 2 & 0 & 1 & 2 & 2 & 2 & 1 & 1 \\
\hline \multicolumn{17}{|c|}{ Panel B: 05/30/2014-06/17/2016 } \\
\hline Index & $\mathrm{N}$ & $\begin{array}{l}\mathrm{N} \\
*\end{array}$ & $\mathrm{~N}^{* *}$ & $\begin{array}{c}\mathrm{N}^{* *} \\
*\end{array}$ & $\begin{array}{l}\mathrm{N} *(+) \\
\text { due to } \\
\text { deprec } \\
\text { iation } \\
\text { of } \\
\text { GBP/ } \\
\text { EUR }\end{array}$ & $\begin{array}{c}\mathrm{N}^{* *}(+) \\
\text { due to } \\
\text { depreciat } \\
\text { ion } \\
\text { of } \\
\text { GBP/EU } \\
\text { R }\end{array}$ & $\begin{array}{c}\mathrm{N} * * *(+) \\
\text { due to } \\
\text { depreciat } \\
\text { ion } \\
\text { of } \\
\text { GBP/EU } \\
\text { R }\end{array}$ & $\begin{array}{c}\mathrm{N}^{*} \\
(-) \\
\text { due to } \\
\text { depreciat } \\
\text { ion of } \\
\text { GBP/EU } \\
\text { R }\end{array}$ & $\begin{array}{c}\text { N** } \\
(-) \\
\text { due to } \\
\text { depreciat } \\
\text { ion of } \\
\text { GBP/EU } \\
\text { R }\end{array}$ & $\begin{array}{c}\mathrm{N} * * * \\
(-) \\
\text { due to } \\
\text { depreciat } \\
\text { ion of } \\
\text { GBP/EU } \\
\text { R }\end{array}$ & $\begin{array}{c}\mathrm{N}^{*}(+) \\
\text { due to } \\
\text { appreci } \\
\text { ation of } \\
\text { GBP/E } \\
\text { UR }\end{array}$ & $\begin{array}{c}\mathrm{N}^{* *}(+) \\
\text { due to } \\
\text { appreci } \\
\text { ation of } \\
\text { GBP/E } \\
\text { UR }\end{array}$ & $\begin{array}{c}\text { N*** } \\
(+) \\
\text { due to } \\
\text { appreci } \\
\text { ation of } \\
\text { GBP/E } \\
\text { UR }\end{array}$ & $\begin{array}{c}\mathrm{N}^{*}(-) \\
\text { due to } \\
\text { appreci } \\
\text { ation of } \\
\text { GBP/E } \\
\text { UR }\end{array}$ & $\begin{array}{c}\mathrm{N}^{* *} \\
(-) \\
\text { due to } \\
\text { appreci } \\
\text { ation } \\
\text { of } \\
\text { GBP/E } \\
\text { UR } \\
\end{array}$ & $\begin{array}{c}\mathrm{N}^{* * * *} \\
(-) \\
\text { due to } \\
\text { appreci } \\
\text { ation } \\
\text { of } \\
\text { GBP/E } \\
\text { UR } \\
\end{array}$ \\
\hline $\begin{array}{l}\text { FTSE } \\
\text { firms }\end{array}$ & 26 & 2 & 4 & 0 & 0 & 1 & 0 & 1 & 1 & 0 & 1 & 1 & 0 & 0 & 1 & 0 \\
\hline $\begin{array}{l}\text { IBEX } \\
\text { firms }\end{array}$ & 10 & 2 & 1 & 1 & 1 & 0 & 1 & 1 & 1 & 0 & 0 & 0 & 0 & 0 & 0 & 0 \\
\hline
\end{tabular}




\begin{tabular}{|c|c|c|c|c|c|c|c|c|c|c|c|c|c|c|c|c|}
\hline $\begin{array}{l}\text { DAX } \\
\text { firms }\end{array}$ & 17 & 0 & 2 & 1 & 0 & 1 & 0 & 0 & 0 & 1 & 0 & 1 & 0 & 0 & 0 & 0 \\
\hline $\begin{array}{l}\text { Total } \\
\text { Sample }\end{array}$ & 53 & 4 & 7 & 2 & 1 & 2 & 1 & 2 & 2 & 1 & 1 & 2 & 0 & 0 & 1 & 0 \\
\hline \multicolumn{17}{|c|}{ Panel C: 06/24/2016-07/20/2018 } \\
\hline Index & $\mathrm{N}$ & $\begin{array}{l}\mathrm{N} \\
*\end{array}$ & $\mathrm{~N}^{* *}$ & $\begin{array}{c}\mathrm{N} * * \\
*\end{array}$ & $\begin{array}{l}\mathrm{N}^{*}(+) \\
\text { due to } \\
\text { deprec } \\
\text { iation } \\
\text { of } \\
\text { GBP/ } \\
\text { EUR }\end{array}$ & $\begin{array}{c}\mathrm{N}^{* *}(+) \\
\text { due to } \\
\text { depreciat } \\
\text { ion } \\
\text { of } \\
\text { GBP/EU } \\
\text { R }\end{array}$ & $\begin{array}{l}\mathrm{N} * * *(+) \\
\text { due to } \\
\text { depreciat } \\
\text { ion } \\
\text { of } \\
\text { GBP/EU } \\
\text { R }\end{array}$ & $\begin{array}{c}\mathrm{N}^{*}(-) \\
\text { due to } \\
\text { depreciat } \\
\text { ion of } \\
\text { GBP/EU } \\
\text { R }\end{array}$ & $\begin{array}{l}\mathrm{N}^{* *}(-) \\
\text { due to } \\
\text { depreciat } \\
\text { ion of } \\
\text { GBP/EU } \\
\text { R }\end{array}$ & $\begin{array}{c}\text { N***(-) } \\
\text { due to } \\
\text { depreciat } \\
\text { ion of } \\
\text { GBP/EU } \\
\text { R }\end{array}$ & $\begin{array}{l}\mathrm{N}^{*}(+) \\
\text { due to } \\
\text { appreci } \\
\text { ation of } \\
\text { GBP/E } \\
\text { UR }\end{array}$ & $\begin{array}{c}\mathrm{N}^{* *}(+) \\
\text { due to } \\
\text { appreci } \\
\text { ation of } \\
\text { GBP/E } \\
\text { UR }\end{array}$ & $\begin{array}{c}\text { N***(+ } \\
) \\
\text { due to } \\
\text { appreci } \\
\text { ation of } \\
\text { GBP/E } \\
\text { UR }\end{array}$ & $\begin{array}{l}\mathrm{N}^{*}(-) \\
\text { due to } \\
\text { appreci } \\
\text { ation of } \\
\text { GBP/E } \\
\text { UR }\end{array}$ & $\begin{array}{c}\mathrm{N}^{* *} \\
(-) \\
\text { due to } \\
\text { appreci } \\
\text { ation } \\
\text { of } \\
\text { GBP/E } \\
\text { UR } \\
\end{array}$ & $\begin{array}{c}\mathrm{N} * * * \\
(-) \\
\text { due to } \\
\text { appreci } \\
\text { ation } \\
\text { of } \\
\text { GBP/E } \\
\text { UR } \\
\end{array}$ \\
\hline $\begin{array}{l}\text { FTSE } \\
\text { firms }\end{array}$ & 26 & 3 & 8 & 1 & 1 & 1 & 1 & 1 & 4 & 0 & 1 & 0 & 0 & 0 & 3 & 0 \\
\hline $\begin{array}{l}\text { IBEX } \\
\text { firms }\end{array}$ & 10 & 0 & 2 & 0 & 0 & 0 & 0 & 0 & 1 & 0 & 0 & 1 & 0 & 0 & 0 & 0 \\
\hline $\begin{array}{l}\text { DAX } \\
\text { firms }\end{array}$ & 17 & 2 & 3 & 1 & 0 & 1 & 0 & 0 & 1 & 0 & 0 & 1 & 1 & 2 & 0 & 0 \\
\hline $\begin{array}{l}\text { Total } \\
\text { Sample }\end{array}$ & 53 & 5 & 13 & 2 & 1 & 2 & 1 & 1 & 6 & 0 & 1 & 2 & 1 & 2 & 3 & 0 \\
\hline \multicolumn{17}{|c|}{ Panel D: Index Currency Exposure } \\
\hline \multicolumn{7}{|c|}{ Full Sample period } & \multicolumn{6}{|c|}{$\underline{05 / 30 / 2014-06 / 17 / 2016}$} & \multicolumn{4}{|c|}{$\underline{06 / 24 / 2016-07 / 20 / 2018}$} \\
\hline & \multicolumn{4}{|c|}{$\begin{array}{l}\text { Exposure due to } \\
\text { depreciation of } \\
\text { GBP/EUR }\end{array}$} & \multicolumn{2}{|c|}{$\begin{array}{c}\text { Exposure } \\
\text { due to appreciation } \\
\text { of GBP/EUR }\end{array}$} & \multicolumn{3}{|c|}{$\begin{array}{l}\text { Exposure due to } \\
\text { depreciation of } \\
\text { GBP/EUR }\end{array}$} & \multicolumn{3}{|c|}{$\begin{array}{l}\text { Exposure due to appreciation of } \\
\text { GBP/EUR }\end{array}$} & \multicolumn{2}{|c|}{$\begin{array}{c}\text { Exposure due to } \\
\text { depreciation of } \\
\text { GBP/EUR }\end{array}$} & \multicolumn{2}{|c|}{$\begin{array}{l}\text { Exposure due to } \\
\text { appreciation of } \\
\text { GBP/EUR }\end{array}$} \\
\hline FTSE & \multicolumn{4}{|c|}{$\begin{array}{c}0.2840 \\
{[0.1951]}\end{array}$} & \multicolumn{2}{|r|}{$\begin{array}{l}-0.1360 \\
{[0.2820]}\end{array}$} & \multicolumn{3}{|c|}{$\begin{array}{c}0.6314 * * * \\
{[0.2215]}\end{array}$} & \multicolumn{3}{|c|}{$\begin{array}{l}0.6356^{*} \\
{[0.3425]}\end{array}$} & \multicolumn{2}{|c|}{$\begin{array}{c}-0.2354 \\
{[0.2288]}\end{array}$} & \multicolumn{2}{|c|}{$\begin{array}{c}-0.6918 * * \\
{[0.2744]}\end{array}$} \\
\hline IBEX & \multicolumn{4}{|c|}{$\begin{array}{c}0.9543 * * * \\
{[0.2624]}\end{array}$} & \multicolumn{2}{|r|}{$\begin{array}{c}0.5121 \\
{[0.3434]}\end{array}$} & \multicolumn{3}{|c|}{$\begin{array}{c}1.5531 * * * \\
{[0.3030]}\end{array}$} & \multicolumn{3}{|c|}{$\begin{array}{c}0.9246 * * \\
{[0.4009]}\end{array}$} & \multicolumn{2}{|c|}{$\begin{array}{c}0.1990 \\
{[0.3510]}\end{array}$} & \multicolumn{2}{|c|}{0.2327} \\
\hline DAX & \multicolumn{4}{|c|}{$1.1009 * * *$} & \multicolumn{2}{|r|}{$0.5905 * *$} & \multicolumn{3}{|c|}{$1.5397 * * *$} & $\begin{array}{r}1.2 \\
{[0} \\
\end{array}$ & \multicolumn{2}{|c|}{$[0.4162]$} & \multicolumn{2}{|c|}{$0.4872 *$} & $\begin{array}{r}0.1 \\
{[0.2} \\
\end{array}$ & \\
\hline
\end{tabular}


Notes: Standard errors of estimates are reported in [brackets]. Standard errors are corrected for autocorrelation and heteroscedasticity with the Newey-West procedure. * significance at the $10 \%$ level, ** significance at the $5 \%$ level, *** significance at the $1 \%$ level. For space reasons, this table offers a summary of the firm exchange rate exposures (Panels A-C) from estimating Eq. (3). Panel D offers the index exchange rate exposures from estimating Eq. (3'). Separated into pre-referendum and post-referendum and full sample periods, we present the number of firms $\mathrm{N}$, the number of significantly exposed firms $\mathrm{N}^{*}$, the number of firms that are significantly positive exposed due to the depreciation of GBP/EUR $\mathrm{N}^{*}(+)($ at $10 \%), \mathrm{N}^{* *}(+)($ at $5 \%), \mathrm{N}^{* * *}(+)($ at $1 \%)$, the number of firms that are significantly negative exposed due to the depreciation of GBP/EUR $\mathrm{N}^{*}(-)($ at $10 \%), \mathrm{N}^{* *}(-)($ at $5 \%), \mathrm{N}^{* * *}(-)($ at $1 \%)$, the number of firms that are significantly positive exposed due to the appreciation of GBP/EUR $\mathrm{N}^{*}(+)($ at $10 \%), \mathrm{N} * *(+)($ at $5 \%)$, $\mathrm{N}^{* * *}(+)($ at $1 \%)$, the number of firms that are significantly negative exposed due to the appreciation of GBP/EUR $\mathrm{N}^{*}(-)($ at $10 \%), \mathrm{N}^{* *}(-)($ at $5 \%), \mathrm{N}^{* * *}(-)($ at $1 \%)$. The full results are available upon request. Linde is negatively exposed due to the depreciation of GBP/EUR and at the same time positively exposed due to the appreciation of GBP/EUR in the full sample and in the post-referendum periods. RR is positively exposed due to the depreciation of GBP/EUR and at the same time negatively exposed due to the appreciation of GBP/EUR in the post-referendum period. ULRV is negatively exposed due to the depreciation of GBP/EUR and at the same time due to the appreciation of GBP/EUR in the post-referendum period. For space reasons, we do not report the R-squares for each regression. The R-squares for FTSE firms and the full sample period range from $9.64 \%$ to $49.38 \%$ with an average value of $29.56 \%$. The R-squares for IBEX firms and the full sample period range from $23.41 \%$ to $54.17 \%$ with an average value of $34.68 \%$. The R-squares for DAX firms and the full sample period range from $18.59 \%$ to $77.73 \%$ with an average value of $50.56 \%$. The R-squares for FTSE firms and the prereferendum period range from $6.78 \%$ to $58.31 \%$ with an average value of $35.44 \%$. The R-squares for IBEX firms and the pre-referendum period range from $24.73 \%$ to $69.02 \%$ with an average value of $43.16 \%$. The R-squares for DAX firms and the pre-referendum period range from $31.08 \%$ to $80.79 \%$ with an average value of $58.99 \%$. Finally, the Rsquares for FTSE firms and the post-referendum period range from $6.54 \%$ to $51.82 \%$ with an average value of $26.64 \%$. The R-squares for IBEX firms and the post-referendum period range from $8.98 \%$ to $40.76 \%$ with an average value of $25.72 \%$. The R-squares for DAX firms and the post-referendum period range from $13.20 \%$ to $72.39 \%$ with an average value of $43.02 \%$. The full results are available upon request. 


\section{Appendix A1.}

We study exchange rate exposures; our data includes stock prices from 53 multinational firms (MNCs) from three developed countries. The firms and industries in our sample are as follows: Retailing (6), Pharmaceuticals (5), Chemicals (5), Automotive (4), Consumer Goods (2), Fast Moving Consumer Goods (2), Building Materials (2), Tobacco (2), Health Care (2), Packaging (2), Steel (2),Industrial (2), Aerospace (2), Engineering (2), Civil Engineering (1),Beverages (1), Tires (1), Apparel (1), Medical Equipment (1), Fashion (1), Food processing (1), Bottling (1), Transportation (1), Meat processing (1), Industrial gas (1) and Housebuilding (1). Below, we briefly describe each firm. We start with the 27 FTSE100 firms. They are all MNCs, listed on the London Stock Exchange (LSE) and are part of the FTSE100 firms.

1. British American Tobacco (BAT) is the largest publicly traded tobacco firm in the world. BAT is headquartered in London and has operations in around 180 countries. It has a primary listing on the LSE. It has secondary listings on other four major stock exchanges.

2. GlaxoSmithKline (GSK) is a British pharmaceutical MNC headquartered in London. GSK was the world's sixth largest pharmaceutical firm as of 2015. It has a primary listing on the LSE. As of August 2016, it was the fourth largest on the LSE. It has a secondary listing on the New York Stock Exchange (NYSE).

3. AstraZeneca (AZN) is a British Swedish pharmaceutical MNC. In 2013, it moved its head office to Cambridge. It is among the world's largest pharmaceutical firms. AZN has a main listing on the LSE and secondary listings on the NYSE and the OMX exchange.

4. Diageo is an alcoholic beverage MNC headquartered in London and it has offices on six continents and 80 countries. It was the world's largest distiller until being overtaken by China's Kweichow Moutai in April 2017. Diageo sells its products in over 180 countries. It has a primary listing on the LSE and a secondary listing on the NYSE.

5. Unilever (ULRV) is a British-Dutch consumer goods MNC headquartered in London and Rotterdam. It is a dual-listed company consisting of Unilever plc, based in London, and Unilever N.V., based in Rotterdam. The two firms operate as a single business. Its products are available in around 190 countries and include food and beverages (about $40 \%$ of its 
revenue), cleaning agents, beauty products, and personal care products. It is Europe's seventh most valuable firm. ULRV owns over 400 brands, and 13 brands with sales of over one billion EUR. ULRV is organized into four main divisions - Foods, Refreshment (beverages and ice cream), Home Care, and Beauty \& Personal Care. In the 2010s, the firm shifted its focus towards health and beauty brands and away from food brands showing slow growth. Unilever plc has a primary listing on the LSE.

6. Reckitt Benckiser Group plc (RB) is a British consumer goods MNC headquartered in Slough. It is a producer of health, hygiene, and home products. It was formed in 1999.

7. Shire Plc was a Jersey-registered, Irish-headquartered pharmaceutical MNC. Shire had its origins in the UK with a base in the US. It had its primary listing on the LSE and a secondary listing on NASDAQ. It was acquired by Takeda Pharmaceutical in January 2019. Its products were available in 100 countries. The main offices were located in Dublin.

8. Imperial Brands plc (IMB) is a British tobacco MNC headquartered in Bristol. It is the world's fourth-largest international cigarette firm measured by market share after BAT and the world's largest producer of cigars. IMB produces has 51 factories worldwide, and its products are sold in over 160 countries. IMB is listed on the LSE. It is the 19th-largest of any company with a primary listing on the LSE.

9. Tesco plc is a multinational groceries and general merchandise retailer with headquarters in Hertfordshire. It is the third-largest retailer in the world measured by gross revenues. It has shops in seven countries across Asia and Europe and is the market leader of groceries in the UK (where it has a market share of around 28.4\%). The firm pulled out of the USA in 2013, but as of 2018 continues to see growth elsewhere. Since the 1960s, Tesco has diversified into areas such as the retailing of books, clothing, electronics, furniture, toys, petrol, software, financial services, telecoms, and internet services. It is the 28thlargest of any company with a primary listing on the LSE.

10. CRH plc is an international group of building materials for the construction industry. The firm is domiciled in Ireland where it ranks as the largest Irish firm. CRH has a primary listing on the LSE and secondary listings on the Irish Stock Exchange and NYSE.

11. BAE Systems plc is a British defense, security, and aerospace MNC. Its headquarters are in London with operations worldwide. It is the largest defense contractor in Europe and among the world's largest defense firms; it was ranked as the third-largest based on applicable 2017 revenues. Its largest operations are in the UK and US. Other major markets 
include Australia, India, and Saudi Arabia, which account for about 20\% of BAE's overall sales. It is the biggest manufacturer in Britain. It was formed in 1999.

12. Rolls-Royce Holdings plc (RR) is a British engineering MNC, which designs, manufactures and distributes power systems for aviation and other industries. RR is the world's second-largest maker of aircraft engines and has major businesses in the marine propulsion and energy sectors. RR was the world's 16th largest defense contractor in 2018 when measured by defense revenues. RR is headquartered in London.

13. Smith \& Nephew plc (SN) is a British medical equipment manufacturing $\mathrm{MNC}$ headquartered in London. It is an international producer of clinical therapy products. Its products are sold in over 120 countries.

14. Burberry Group PLC is a luxury fashion house and MNC, headquartered in London. It focuses on and distributes trench coats, ready-to-wear, outerwear, fashion accessories, fragrances, sunglasses, and cosmetics. In 2015, Burberry ranked 73rd in Interbrand's Best Global Brands report, alongside Louis Vuitton and Prada. It has stores in 51 countries.

15. Associated British Foods plc (ABF) is a British food processing and retailing MNC whose headquarters are in London. Its ingredients division is the world's second-largest producer of both sugar and baker's yeast and a major producer of other ingredients. Its grocery division is a major manufacturer of both branded and private label grocery products. Its retail division, Primark, has around 345 stores across Europe.

16. Next (NXT), is a British clothing, footwear, and home products retailer headquartered in Leicestershire. It has around 700 stores, of which 500 are in the UK and 200 across Europe, Asia, and the Middle East. NXT is the largest clothing retailer by sales in the UK, having overtaken Marks\& Spencer in early 2012and 2014.

17. Mondi Group is an international packaging and paper group with around 100 production sites across more than 30 countries, predominantly in Europe, Russia, North America, and South Africa. It is fully integrated across the packaging and paper value chain - from the growing of wood and the manufacturing of pulp and paper to the conversion of packaging papers into corrugated packaging, industrial bags, extrusion coatings, and release liner. It has listings on the Johannesburg Stock Exchange and the LSE.

18. The Smurfit Kappa Group plc is Europe's leading corrugated packaging firm and one of the leading firms in the world. SKG specializes in manufacturing paper-based packaging, with a network of paper, recycling, and forestry operations. It is an integrated producer, with 
packaging plants sourcing the major part of their material requirements from the company's paper mills. In turn, the sourcing of recovered fiber and wood for the mills is managed through a combination of reclamation and forestry operations and purchases from third parties. It operates across 35 countries. Its head office is in Dublin.

19. Johnson Matthey (JMAT) is British specialty chemicals and sustainable technologies MNC headquartered in the UK.

20. Kingfisher plc is a British retailing MNC headquartered in London, with regional offices located across the UK and Ireland. It is the largest home improvement retailer in Europe, and the third largest in the world (behind The Home Depot and Lowe's). It has stores, in 10 countries across Europe. Kingfisher is also the third largest commercial property developer in the UK, with more than 1,200 buildings ranging from apartments to hotels.

21. Smiths Group plc (SMIN) is a British multinational diversified engineering business headquartered in London. It has operations in over 50 countries. SMIN has five divisions. Smiths Detection is the world's largest manufacturer of sensors for the detection of explosives, weapons, chemical agents, biohazards, narcotics, and contraband. John Crane is a manufacturer of seals and associated products for the process industries. Smiths Medical is a manufacturer and supplier of specialty medical devices and equipment. Smiths Interconnect is a manufacturer of electronic and radio frequency components. Flex-Tek is a supplier of components to heat and move fluids and gases.

22. Croda International plc is a British specialty chemicals MNC based at the East Riding of Yorkshire. The firm's products include dietary supplements containing specialty lipids, such as omega-3 oils. Fatty acid amides, which add "slip" to plastic surfaces, so plastic bags, can be peeled apart easily. These products are sold to other manufacturing companies. Croda has factories in the UK and many countries around the world.

23. Coca-Cola HBC A.G. $(\mathrm{CCH})$ is the world's third-largest Coca-Cola anchor bottler in terms of volume with sales of more than 2 billion unit cases. Coca-Cola HBC's shares are listed on the LSE with a secondary listing on the Athens Stock Exchange. $\mathrm{CCH}$ has been named the industry leader among beverage companies in the 2014 Dow Jones Sustainability Index (DJSI). It is headquartered in Zug, Switzerland.

24. Marks \& Spencer Group plc $(M \& S)$ is a major British multinational retailer headquartered in London that specializes in selling clothing, home products, and luxury food products. In 1998, the company became the first British retailer to make a pre-tax profit of over 
$£ 1$ billion although subsequently, it went into a sudden slump. In recent years, its clothing sales have fallen whilst food sales have increased. In May 2018, it was confirmed that over 100 stores would have closed by 2022 in a "radical" plan.

25. Barratt Developments plc is one of the largest residential property development firms in the UK operating a network of over 30 divisions. It is located at Leicestershire.

26. EVRAZ plc is a vertically integrated steel making and mining MNC with headquarters in London. It has operations mainly in Russia, but also across the world.

We then move to the10 IBEX35 firms. They are all MNCs, and part of the IBEX35 firms.

27. Industria de Diseño Textil, S.A. (ITX) in Textile Design Industry is a Spanish clothing MNC headquartered in Arteixo. Inditex, the biggest fashion group in the world, operates in 93 markets worldwide. The company's flagship store is Zara. The majority of its stores are corporate-owned, while franchises are mainly conceded in countries where corporate properties cannot be foreign-owned. The firm operates a unique business model: instead of committing a large percentage of production for the next fashion season, the company commits a small amount and uses customer feedback and a production network to replenish stores with new and different products weekly.

28. Ferrovial, S.A. is a Spanish multinational company involved in the design, construction, financing, operation (DBFO) and maintenance of transport infrastructure and urban services. The company is headquartered in Madrid. Ferrovial operates through four divisions in over 15 countries. Its Highway division finances and operates toll roads. The Airport sector has developed and produced airports. Its Construction business designs and constructs public and private works such as roads, highways, airports, and buildings. The company's Services sector oversees the maintenance of infrastructures, facilities and buildings, the collection and treatment of waste, and other types of public service.

29. Actividades de Construcción y Servicios, S.A. (ASC) is an MNC dedicated to civil and engineering construction, all types of services and telecommunications. It is one of the leading construction firms in the world. The company was founded in 1997. Its headquarters are in Madrid and it is listed on the Bolsa de Madrid.

30. Grifols is an MNC and a pharmaceutical and chemical manufacturer. It produces blood plasma-based products, a field in which it is the European leader and largest worldwide, the firm also supplies devices and instruments, for clinical testing laboratories. 
31. ArcelorMittal S.A. (MT) is an MNC and a steel manufacturing firm headquartered in Luxembourg. MT was formed in 2006 and it is the world's largest steel producer; it is ranked 123 in the 2017 Fortune Global 500 ranking of the world's biggest corporations.

32. Siemens Gamesa Renewable Energy S.A. (SGRE) is a Spanish engineering company located in Zamudio. It manufactures wind turbines and provides onshore and offshore wind services. It is the world's second largest wind turbine manufacturer.

33. Viscofan is a Spanish manufacturer of casings for meat products. Viscofan has a commercial presence in over 100 countries around the world. It is the only world producer with the capacity to manufacture the four main technologies available on the casings or artificial casings market. The company is trading in the Madrid Stock Exchange General Index.

34. Acerinox, S.A. is a stainless steel manufacturing conglomerate group based in Spain. Nissan holds approximately $15 \%$ of Acerinox as of April 2010. The headquarters are in Madrid. As for 2008, the company was the world's largest producer of stainless steel.

35. CIE Automotive is an industrial group specialized in supplying components and subassemblies for the automotive market. It is listed on the Madrid and Bilbao stock markets, and it has a presence in four continents and 15 countries. CIE focuses its resources on three business areas: Automotive components (present in nine countries), Biofuels, (and Dominion, Technological solutions and services.

36. Distribuidora Internacional de Alimentación, S.A. (DIA) is an international supermarket chain, which as of 2012 operates stores internationally, making it Europe's third largest food sector franchiser. DIA is a discount supermarket chain, which follows a policy of reduction of prices by means of minimizing operational costs. The furniture and decoration of the store are minimal. Costs are also reduced by limiting the choice of products to a narrow selection of European brand names and white-label DIA brand goods. The chain also sells small appliances. Its policy of communication is based on mass media campaigns as well as periodic flyers featuring products, which are on special sale.

We then move to the17DAX30 firms. They are all MNCs, and part of the DAX30 firms.

37. BMW AG is an MNC currently producing automobiles and motorcycles, headquartered in Munich. In 2015, BMW was the world's twelfth largest producer of motor vehicles. 
38. Volkswagen AG is an automotive manufacturing MNC headquartered in Wolfsburg. It designs, manufactures and distributes vehicles, motorcycles, engines, and turbo machinery and offers related services including financing, leasing and fleet management. In 2016, it was the world's largest automaker by sales, overtaking Toyota and keeping this title in 2017 and 2018.It has the largest market share in Europe for over two decades. It ranked seventh in the 2018 Fortune Global 500 list of the world's largest companies. It is divided into two primary divisions, the Automotive Division and the Financial Services Division. It also has two major joint ventures in China. It has operations in approximately 150 countries. The firm's operations in China have grown rapidly in the past decade with the country becoming its largest market. Volkswagen has a primary listing on the Frankfurt Stock Exchange (FSE), where it is a constituent of the Euro Stoxx 50 stock market index (STOXX), and secondary listings on other major exchanges. Volkswagen delisted from the LSE in 2013.

39. Adidas AG is an MNC, founded and headquartered in Bavaria. Adidas designs and manufactures shoes, clothing, and accessories. It is the largest sportswear manufacturer in Europe, and the second largest in the world, after Nike.

40. Daimler AG is an automotive MNC, headquartered in Stuttgart. By unit sales, it is the thirteenth-largest car manufacturer and is the largest truck manufacturer in the world. It also provides financial services. It is a component of the STOXX.

41. Continental AG is MNC specializing in parts for the automotive and transportation industries. It is based in Hanover and it is the world's fourth-largest tire manufacturer. After acquiring Siemens AG's VDO automotive unit in 2007, Continental was ranked third in global OEM automotive parts sales in 2012. In 2012, Continental returned to the benchmark DAX index of 30.

42. Henkel AG is a chemical and consumer goods MNC headquartered in Düsseldorf, Germany. It is active in both the consumer and industrial sector. The firm is organized into three globally operating business units (Laundry \& Home Care, Beauty Care, and Adhesive Technologies). In the fiscal year 2017, Henkel reported sales of over 20 billion EUR. More than 80 percent of its employees work outside of Germany.

43. Beiersdorf AG is an MNC based in Hamburg, producing personal-care products and pressure-sensitive adhesives. Although its shares are publicly listed, Beiersdorf is controlled by Maxingvest AG, which directly owns $50.49 \%$ of shares. 
44. Bayer AG is a pharmaceutical and life sciences MNC, headquartered in Leverkusen. It is one of the largest pharmaceutical firms in the world. Bayer's areas of business include pharmaceuticals; consumer healthcare products; agricultural chemicals and biotechnology products; and high-value polymers. The firm is a component of STOXX. In 2014, it acquired Merck \& Co.'s consumer business.

45. Fresenius SE \& Co. KGaA is a health care MNC based in Bad Homburg. It provides products and services for dialysis, hospitals and medical care. In addition, the company focuses on hospital management as well as on engineering and services for medical centers and other health care facilities. The company is a component of STOXX.

46. Merck is a pharmaceutical, chemical, and life sciences MNC headquartered in Darmstadt. It is the world's oldest operating chemical and pharmaceutical firm and one of the largest pharmaceutical firms in the world. Merck operates in Europe, Africa, Asia, Oceania, and the Americas. In 2015, it adopted a new uniform brand identity for all its subsidiaries.

47. Fresenius Medical Care is an MNC specializing in the production of medical supplies, primarily to facilitate or aid renal dialysis. It is $30 \%$ owned by the health care company Fresenius. Fresenius Medical Care operates more than 40 production sites on all continents. Its largest plants are in the U.S., Germany, and Japan.

48. Siemens AG is a conglomerate MNC headquartered in Berlin and Munich and the largest industrial manufacturing company in Europe with branch offices abroad. The principal divisions of the company are Industry, Energy, Healthcare and Infrastructure \& Cities, which represent its main activities. It produces medical diagnostics equipment and its medical health-care division, which generates about $12 \%$ of the company's total sales, is its second-most profitable unit, after the industrial automation division. The company is a component of STOXX. Siemens reported revenue of $€ 83$ billion in 2018.

49. BASF SE is a chemical MNC and the largest chemical producer in the world. The BASF operates six integrated production sites in all continents. Its headquarters are in Ludwigshafen. BASF has customers in over 190 countries. It is currently expanding its international activities with a focus on Asia. BASF is listed on the FSE, LSE, and Zurich Stock Exchange. BASF delisted from the NYSE in 2007. It is a component of STOXX.

50. HeidelbergCement (HEI) is one of the largest building material MNCs in the world headquartered in Heidelberg. HEI is the number one producer of construction aggregates, the number two in cement and number three in ready-mixed concrete worldwide. 
51. ThyssenKrupp AG is an MNC with a focus on industrial engineering and steel production. The company is based in Duisburg and Essen. It is one of the world's largest steel producers, ranked tenth largest worldwide by revenue in 2015.In addition to steel production, ThyssenKrupp's products range from machines and industrial services to highspeed trains, elevators, and shipbuilding. Subsidiary ThyssenKrupp Marine Systems also manufactures frigates, corvettes, and submarines.

52. Linde plc is an Irish-domiciled chemical MNC. It is the world's largest industrial gas firm by market share as well as revenue. Linde shares are traded in Germany and the US and included in DAX 30 and S\&P 500 stock market indices. In 2006, it acquired its UK based competitor the BOC Group and subsequently disposed of its non-gas interests. In 2005, Linde AG and BOC together had $21 \%$ of the world's market in industrial gases.

53. Covestro is an MNC and a world-leading supplier of high-tech polymer materials. They are the partner for a wide variety of industries. Covestro is a Bayer spin-off formed in the fall of 2015. Covestro shares were first offered on the FSE in 2015. Bayer sold its entire remaining stake in May 2018. The main industries served are automotive manufacturing and supply, electrical engineering and electronics, construction and home products, and sports and leisure. Their products include coatings, adhesives, and polyurethanes. 


\section{Appendix A2.}

Table A2.

This table compares and contrasts the base case scenario results with the results using seemingly unrelated regressions (SUR) as a robustness check.

\begin{tabular}{|c|c|c|c|c|}
\hline Hypothesis & Markets & Time Period & Base Case scenario & SUR Method \\
\hline \multirow[t]{9}{*}{$\mathrm{H} 2$ and $\mathrm{H} 3$} & \multirow[t]{3}{*}{ FTSE } & Full Sample & $\begin{array}{c}11 \text { firms are exposed at least at } 10 \% \text {, five } \\
\text { positive and six negative }\end{array}$ & $\begin{array}{c}12 \text { exposed at least at } 10 \% \text {, five positive and } \\
\text { seven negative }\end{array}$ \\
\hline & & Pre-referendum & SMIN positively exposed at $5 \%$ & SMIN positively exposed at $5 \%$ \\
\hline & & Post-referendum & $\begin{array}{c}\text { Seven (Nine) exposed at 5\%(10\%), six } \\
\text { negative and three positive }\end{array}$ & $\begin{array}{l}\text { Nine (11) exposed at least at } 5 \%(10 \%), \\
\text { seven negative and four positive }\end{array}$ \\
\hline & \multirow[t]{3}{*}{ IBEX } & Full Sample & ITX positively exposed at $1 \%$ & ITX positively exposed at $1 \%$ \\
\hline & & Pre-referendum & ITX positively exposed at $5 \%$ & ITX positively exposed at $5 \%$ \\
\hline & & Post-referendum & No firm exposed & No firm exposed \\
\hline & \multirow[t]{3}{*}{ DAX } & Full Sample & Merck positively exposed at $10 \%$ & $\begin{array}{c}\text { Adidas positively exposed at 5\% and Merck } \\
\text { and Covestro at } 10 \%\end{array}$ \\
\hline & & Pre-referendum & Merck positively exposed at $1 \%$ & Merck positively exposed at $1 \%$ \\
\hline & & Post-referendum & $\begin{array}{l}\text { Siemens positively exposed at } 5 \% \text { and } \\
\text { HEI at } 10 \%\end{array}$ & $\begin{array}{l}\text { Adidas and Siemens positively exposed at } \\
5 \% \text { and Covestro at } 10 \%\end{array}$ \\
\hline
\end{tabular}


Table A2-continued

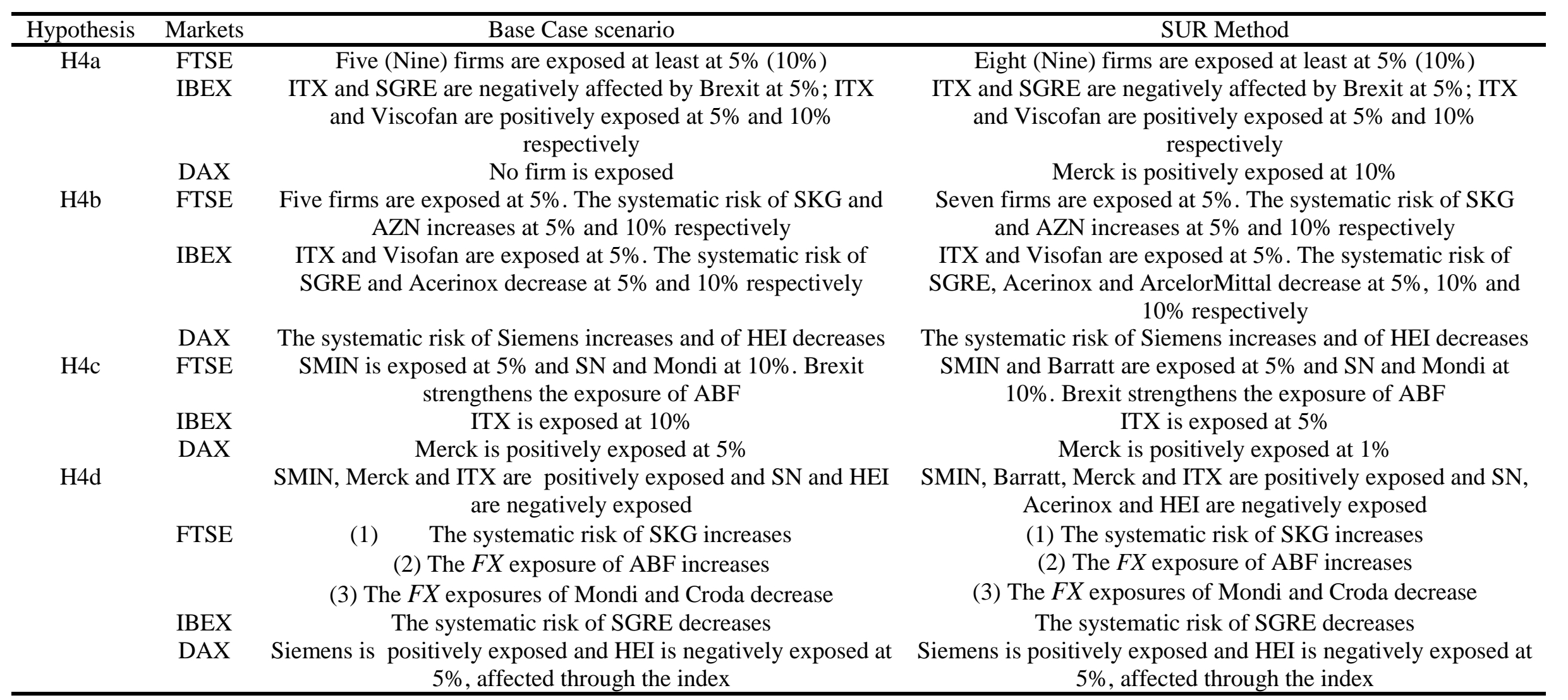


Table A2-continued

\begin{tabular}{ccc}
\hline Hypothesis & Time Periods & Markets \\
\hline H5 & Full Sample & FTSE
\end{tabular}

Base Case scenario

(1) Two (five) firms are exposed to appreciations at least at $5 \%(10 \%)$

(2) Eight firms are exposed at either appreciations or depreciations at least at $10 \%$

(3) Four firms are exposed to changes but not to depreciation or appreciation

(4) Tesco is negatively exposed to appreciation at $10 \%$, not to changes

IBEX (1) ITX is positively exposed to depreciation at $1 \%$; Viscofan is positively exposed to appreciation at $1 \%$

(2) ITX and Viscofan are exposed to changes

DAX Three firms are exposed to appreciations and two

firms are exposed to depreciations but none of these firms are exposed to changes

Pre-referendum FTSE

Five firms are exposed at either appreciations or depreciations at least at $10 \%$

IBEX Four firms are exposed to depreciations and none to appreciations

DAX Two firms are exposed to depreciations and BMW is positively exposed to appreciation

Post-referendum FTSE (1) 12 firms are exposed to either appreciations or depreciations

(2) Three firms are exposed before and after the vote

(3) KGF and SMIN are exposed before but not after the vote

(4) Most firms are exposed after the vote

(5) RR and $\mathrm{SN}$ are exposed before the vote, the exposure intensifies after the vote

(6) NXT is exposed to appreciation before the vote and to depreciation after the vote

IBEX (1) FER is negatively exposed to depreciation and
SUR Method

(1) Five (six) firms are exposed to appreciations at least at $5 \%(10 \%)$

(2) 10 firms are exposed at either appreciations or depreciations at least at $10 \%$

(3) Three firms are exposed to changes but not to depreciation or appreciation

(4) Tesco is negatively exposed to appreciation at $10 \%$, not to changes

(1) ITX is positively exposed to depreciation at $1 \%$; Viscofan is positively exposed to appreciation at $1 \%$

(2) ITX and Viscofan are exposed to changes

Three firms are exposed to appreciations and

Covestro is exposed to depreciations but none of these firms are exposed to changes

Four firms are exposed at either appreciations or depreciations at least at $10 \%$

Four firms are exposed to depreciations and none to appreciations

Two firms are exposed to depreciations and BMW is positively exposed to appreciation

(1) 12 firms are exposed to either appreciations or depreciations

(2) Two firms are exposed before and after the vote

(3) KGF and SMIN are exposed before but not after the vote

(4) Most firms are exposed after the vote

(5) RR is exposed not before but after the vote. SN is exposed before the vote, the exposure intensifies after the vote

(6) NXT is exposed to appreciation before and to depreciation after the vote

(1) FER is negatively exposed to depreciation and 
Viscofan is positively exposed to appreciation at 5\%

(2) ITX, Grifols, Acerinox and CIE are exposed before but not after the vote

DAX Five firms are exposed to either appreciations or depreciations
Viscofan is positively exposed to appreciation at 5\% (2) ITX, Grifols, Acerinox, and CIE are exposed before but not after the vote

Four firms are exposed to either appreciations or depreciations

Notes: The full results are available upon request. 